\title{
Eruptive history of the Late Quaternary Ciomadul (Csomád) volcano, East Carpathians, part II: magma output rates
}

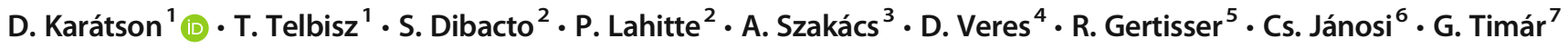

Received: 11 October 2018 / Accepted: 5 March 2019 / Published online: 29 March 2019

(C) The Author(s) 2019

\begin{abstract}
This study, which builds on high-precision unspiked Cassignol-Gillot K-Ar age determinations, presents an advanced DEMbased volumetrical analysis to infer long-term magma output rates for the Late Quaternary Ciomadul (Csomád) dacitic lava dome complex (East Carpathians, Romania). The volcanic field of Ciomadul developed on the erosional surface of Lower Cretaceous flysch and $\sim 2$ Ma old andesites and experienced an extended eruptive history from $\sim 850$ to $<30$ ka. Predominantly effusive activity took place during the first stage $(\sim 850$ to $\sim 440 \mathrm{ka})$, producing volumetrically minor, isolated, peripheral domes. Subsequently, after a $\sim 250 \mathrm{ky}$ repose interval, a voluminous central dome cluster developed in the second stage $(\sim 200$ to $<$ $30 \mathrm{ka})$. During the youngest phase of evolution $(\sim 60$ to $<30 \mathrm{ka})$, highly explosive eruptions also occurred, resulting in the formation of two craters (Mohos and St. Ana). The calculated $\sim 8.00 \pm 0.55 \mathrm{~km}^{3}$ total volume of the lava domes, which includes the related volcaniclastic $\left(1.57 \mathrm{~km}^{3}\right)$ as well as erosionally removed $\left(0.18 \mathrm{~km}^{3}\right)$ material, is in line with dimensions of other medium-sized dacitic lava domes worldwide. This volume was extruded at an average long-term magma output rate of $9.76 \mathrm{~km}^{3} /$ My $\left(0.0098 \mathrm{~km}^{3} / \mathrm{ky}\right)$. However, most of the domes $\left(7.53 \pm 0.51 \mathrm{~km}^{3}\right)$ were formed in the 200 to $<30$ ka period, implying a significantly increased magma output rate of $37.40 \mathrm{~km}^{3} / \mathrm{My}\left(0.0374 \mathrm{~km}^{3} / \mathrm{ky}\right)$, more than 30 times higher than in the first stage. Within these long-term trends, individual lava domes of Ciomadul (e.g. those with volumes between 0.02 and $0.40 \mathrm{~km}^{3}$ ) would have been emplaced at much higher rates over a period of years to tens of years. The active periods, lasting up to hundreds of years, would have been followed by repose periods $\sim 30$ times longer. The most recent eruption of Ciomadul has been dated here at $27.7 \pm 1.4 \mathrm{ka}$. This age, which is in agreement with radiocarbon dates for the onset of lake sediment accumulation in St. Ana crater, dates fragmented lava blocks which are possibly related to a disrupted dome. This suggests that during the last, typically explosive, phase of Ciomadul, lava dome extrusion was still ongoing. In a global context, the analysis of the volumetric dynamism of Ciomadul's activity gives insights into the temporal variations in magma output; at lava domes, short-term (dayor week-scale) eruption rates smooth out in long-term (millenia-scale) output rates which are tens of times lower.
\end{abstract}

Keywords Lava dome $\cdot$ Magma output rate $\cdot$ DEM-volumetry $\cdot$ K-Ar chronology $\cdot$ Carpathian volcanism

Editorial responsibility: S. Self

Electronic supplementary material The online version of this article (https://doi.org/10.1007/s00445-019-1287-8) contains supplementary material, which is available to authorized users.

D. Karátson

dkarat@ludens.elte.hu

1 Department of Physical Geography, Eötvös University, Pázmány s. 1/C, Budapest H-1117, Hungary

2 GEOPS, Univ. Paris-Sud, CNRS, Université Paris-Saclay, Rue du Belvédère, Bât. 504, 91405 Orsay, France

3 Institute of Geodynamics, Romanian Academy, Jean-Louis Calderon St. 19-21, 020032 Bucureşti, Romania
4 Institute of Speleology, Romanian Academy, Clinicilor 5, 400006 Cluj-Napoca, Romania

5 School of Geography, Geology and the Environment, Keele University, Keele ST5 5BG, UK

6 Inimii 3/14, RO-530225 Miercurea Ciuc, Romania

Department of Geophysics and Space Science, Eötvös University, Pázmány s. 1/C, Budapest H-1117, Hungary 


\section{Introduction}

Lava domes, typically monogenetic landforms (Smith and Németh 2017) resulting from viscous lava extrusion (Davidson and de Silva 2000; Fink and Anderson 2017), occur in a wide range of geodynamic or volcanic settings. In most cases, they are part of composite volcanic edifices, often called lava dome complexes (Lockwood and Hazlett 2010), or belong to silicic caldera systems, where they form during less explosive volcanic periods (Wohletz and Heiken 1992). However, they can also occur as isolated volcanic features, ranging from lava dome fields to separate landforms, which are typical along the Inner Carpathian Volcanic Range (Lexa et al. 2010).

The short-term temporal evolution of lava dome fields and relation with output rate is quite well constrained at individual dome systems (e.g. Riggs et al. 1997; Scott et al. 2008; Ryan et al. 2010; Fink and Anderson 2017). However, the long-term tempo of magma output is much less studied. Exceptions include examples from large, intra-plate volcanic fields such as the San Francisco Volcanic Field, which displays a number of volcano types: scoria cones, lava domes and a composite cone (Tanaka et al. 1986; Wood and Kienle 1990; Priest et al. 2001; Karátson et al. 2010a). This paper focuses on the volcanic arcrelated Ciomadul (Csomád) ${ }^{1}$ lava dome complex (Mason et al. 1998) that marks the southernmost terminus of the East Carpathian volcanic range in Romania (Fig. 1). Ciomadul, a long-lived volcano, developed over the past $\sim 850 \mathrm{ky}$ (Szakács et al. 2015; Molnár et al. 2018; Lahitte et al. this volume). Our main objective is to present the dynamism of the eruptive history over this period and to compare long-term magma output to short-term eruptive rates.

The volcanic evolution of Ciomadul has been intensely studied in the past decade (e.g. Karátson 2007; Vinkler et al. 2007; Harangi et al. 2010, 2015; Popa et al. 2012; Karátson et al. 2013, 2016; Kiss et al. 2014; Szakács et al. 2015). However, there are a number of issues related to the spatial and temporal evolution that have not yet been clarified. In particular, Ciomadul (Fig. 2), which consists of a central, superimposed dome complex and a few scattered peripheral domes (Szakács et al. 2015), evolved during two somewhat contrasting stages. In our paper, we demonstrate that, in terms of magma output, distinguishing between these stages is fundamental. The first stage, lasting from $\sim 850$ to $\sim 440 \mathrm{ka}$ (Molnár et al. 2018; Lahitte et al. this volume), was marked by typically low lava dome growth rates, characterised by mostly effusive activity (Szakács et al. 2015). The second stage, beginning at $\sim 200 \mathrm{ka}$ (Lahitte et al. this volume) and ending at less than $30 \mathrm{ka}$ (Karátson et al. 2016; Wulf et al.

\footnotetext{
${ }^{1}$ Official Romanian names, when mentioned at first, are followed by locally used Hungarian names (in brackets), which is helpful for the reader in finding names on local maps
}

2016), was more explosive; in addition to occasional Vulcanian eruptions, both Plinian and phreatomagmatic eruptions occurred, especially during the final phase of activity (Szakács et al. 2015; Karátson et al. 2016, 2017; Wulf et al. 2016; Veres et al. 2018). This latest explosive phase resulted in the formation of the two prominent craters in the central part of the volcanic complex that truncate the main domes: Mohoș (Mohos), hosting a peat bog, and St. Ana (Szent Anna), hosting a lake (Fig. 2).

To constrain the eruptive activity, in particular, magma output rates as well as the temporal and geomorphological relationships of subsequent domes, precise dating is fundamental. Whereas there is largely a consensus that the final explosive phase was confined to $\sim>50$ to $\sim 30 \mathrm{ka}$ (Moriya et al. 1995, 1996; Harangi et al. 2015; Szakács et al. 2015; Karátson et al. 2016), the timing of the extended, preceding, period of lava dome growth has remained poorly constrained, although knowledge about the onset of volcanism has recently been improved by (U-Th)/He dating (Molnár et al. 2018). In the first part of this work (Lahitte et al. this volume), Cassignol-Gillot unspiked K-Ar dating (Gillot and Cornette 1986) has been applied to provide nine new high-precision K-Ar ages for selected samples, giving insight into the whole lifetime of Ciomadul. While Lahitte et al. (this volume) focused on the implications for the evolution of the magmatic feeding system, we here consider the implications for the volumetric evolution of the dome complex, as discussed previously in Karátson et al. (2018a, b). Thus, in the second part of this work, we take the new ages obtained by Lahitte et al. (this volume), complemented by four further Cassignol-Gillot $\mathrm{K} / \mathrm{Ar}$ age determinations, which clarify the age of the basal surface and the last activity of Ciomadul. These ages make it possible to analyse the volumetrical dynamism of the lava dome complex over the past 850 ky combining the age data with a digital elevation model (DEM)-based approach, and to infer the volcano-geomorphological evolution of Ciomadul through its whole lifetime.

\section{Geological setting and major evolutionary issues of Ciomadul}

From a geodynamic point of view, the NNW-SSE trending East Carpathian volcanic range (Fig. 1) is related to a postcollisional setting (Mason et al. 1998; Seghedi et al. 1998, 2004; Chalot-Prat and Gîrbacea 2000). The volcanic activity developed subsequent to a W-directed, retreating subduction of a land-locked narrow oceanic basin between the Tisia block and the East European platform (Mason et al. 1998; Seghedi et al. 2004). Due to the migration of the magma-generating zone at mantle depths (Mason et al. 1998), a time-space migration of volcanic activity occurred over the past $\sim 10 \mathrm{My}$ (Pécskay et al. 1995, 2006; Szakács and Seghedi 1995). During the timespan of volcanism, magma output gradually 


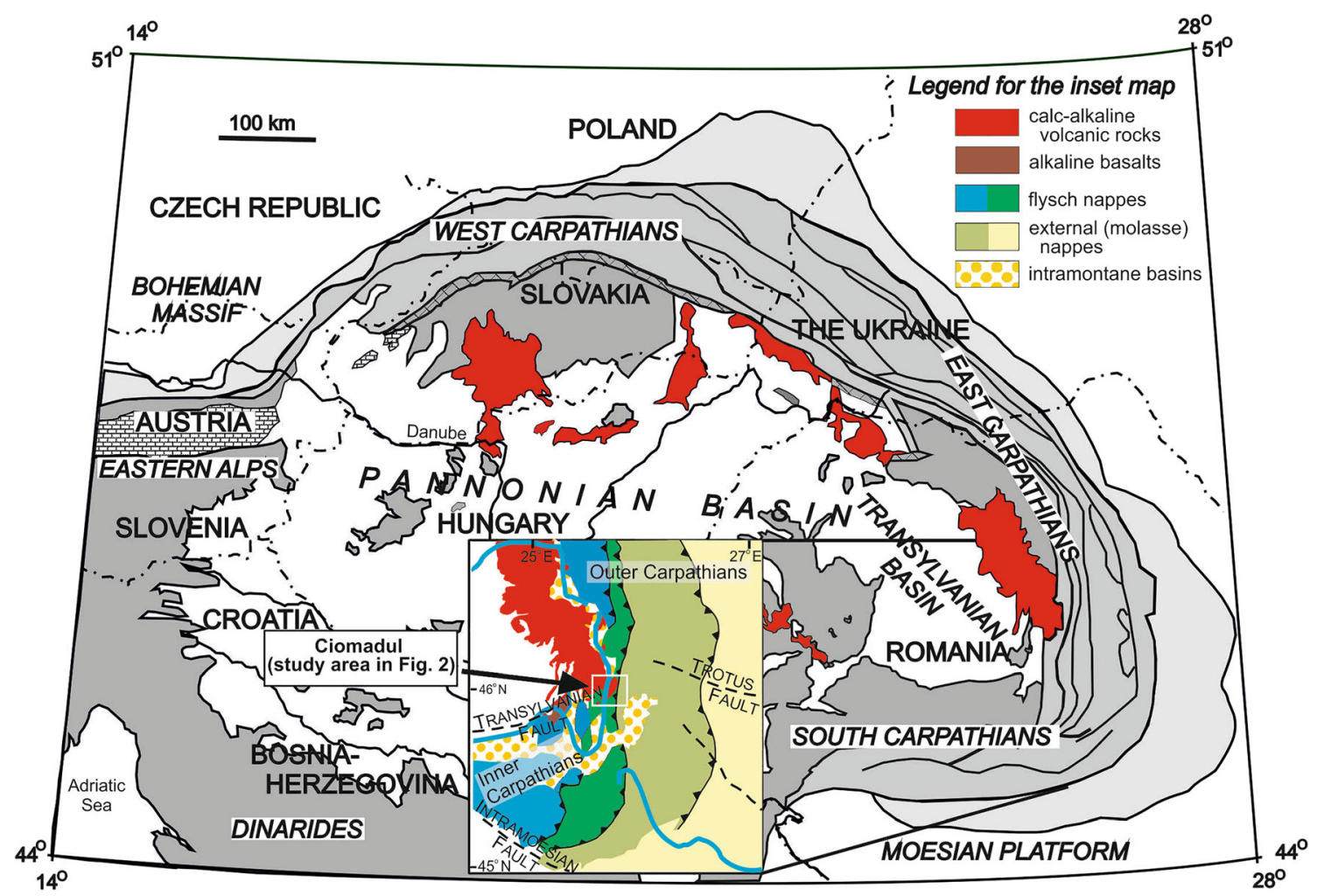

Fig. 1 Tectonic framework and geological setting of Ciomadul (Csomád) volcano

decreased with time (Szakács et al. 1993; Karátson and Timár 2005; Szakács et al. 2015).

The chain terminus of the range crosscuts the fold-andthrust orogenic belt of the East Carpathians in the Ciomadul region (Fig. 1; Szakács et al. 1993). At Ciomadul, the lava domes were emplaced mostly on Cretaceous flysch (a sandstone-shale band forming the outer Carpathians: Săndulescu 1988) and, at their western side in the Tuşnad (Tusnád) Gorge, on Early Pleistocene andesites and dacites of the adjacent Pilişca (Piliske) volcano (Szakács et al. 2015). In some places, Ciomadul pyroclastic rocks overlie a palaeosol that developed on top of fluvial terrace gravels (Szakács et al. 2015). Direct contacts of Ciomadul dacite lavas or pyroclastics with underlying andesites belonging to Pilişca volcanic edifice, exposed along the Olt riverbed, also occur (Fig. 2).

The prevailing rock type of Ciomadul is porphyritic dacite $\left(\mathrm{SiO}_{2}=63-68 \mathrm{wt} \% ; \mathrm{K}_{2} \mathrm{O}=3.0-3.5 \mathrm{wt} \%\right.$ : Szakács and Seghedi 1986; Kiss et al. 2014; Lahitte et al. this volume), with a mineral assemblage of plagioclase, amphibole, biotite, occasional clinopyroxene, orthopyroxene, quartz, K-feldspar, olivine, and minor apatite, titanite, zircon and allanite (Jánosi 1983; Szakács and Seghedi 1986; Mason et al. 1998; Kiss et al. 2014; Harangi et al. 2015). The petrogenetic evolution of the volcanism at the chain terminus has been discussed by Seghedi et al. (1987), Szakács et al. (1993), Mason et al.
(1998), Vinkler et al. (2007), Kiss et al. (2014) and Lahitte et al. (this volume).

Geographically, the Ciomadul lava dome complex is separated from the main andesitic volcanic range (the Călimani[Kelemen]-Gurghiu[Görgényi]-Harghita[Hargita] Mountains) by the river Olt along the deeply cut Tuşnad Gorge (Fig. 2). The chain terminus east of the gorge is called the "Ciomadul-Puturosu" (Csomád-Büdös) Hills in the geographical literature (Bányai 1964) and has developed over an area of ca. $75 \mathrm{~km}^{2}$. The central, much larger and younger volcanic dome area with some peripheral domes (Fig. 2) is separated toward the southeast and east by the uplifted Cretaceous flysch zone, which is cut by the older Dealul Mare (Hegyes-tetö) dome and the volumetrically insignificant, isolated and older dome remnants (partly volcanic necks) of Puturosu (Büdös) and Balvanyos (Bálványos). The whole Ciomadul-Puturosu area was mapped by Szakács and Seghedi (1990), with the resultant map also published in simplified form by Szakács et al. (2015).

To the southeast of the Ciomadul-Puturosu dacitic dome cluster, the isolated dome of Dealul Mare was also considered to belong to the older Ciomadul domes by Szakács et al. (2015) who obtained a K-Ar age of $1.02 \pm 0.07$ (all age dates are reported with $1 \sigma$ uncertainty). Although Dealul Mare is andesitic in composition (Szakács and Seghedi 1986), there are five features which suggest that the dome is part of the 


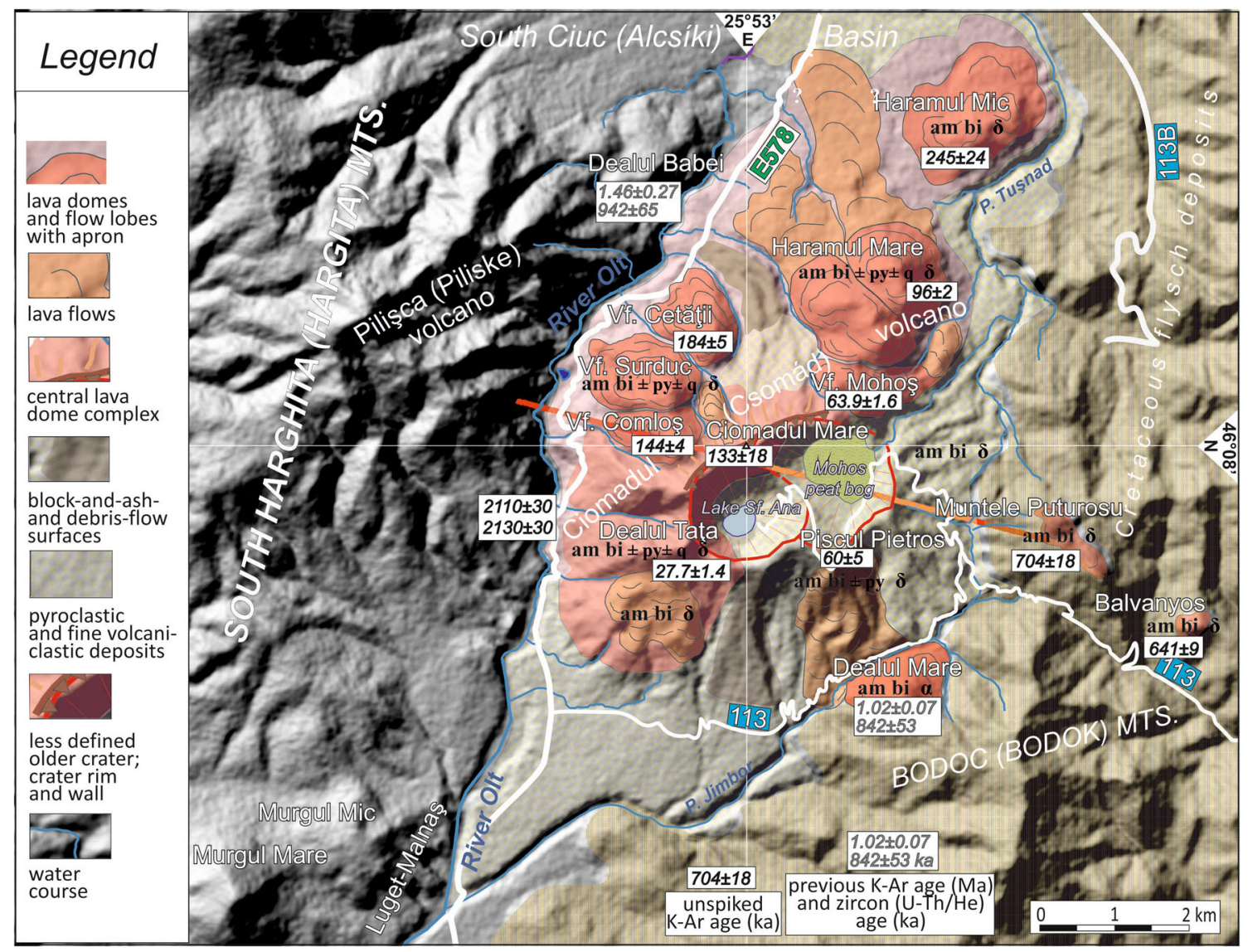

Fig. 2 Volcano-geomorphological map with radiometric ages, draped over SRTM DEM. Cassignol-Gillot K-Ar ages in black, placed in white quadrangles, are reported with $1 \sigma$ error. All ages refer to massive lava dome rocks except the $27.7 \pm 1.4 \mathrm{ka}$ age on the SW slopes of St. Ana crater, which has been obtained on fragmented lava blocks, probably

Ciomadul dome complex: (1) its position is close to the central dome cluster (closer than some of the peripheral dacitic domes such as Haramul Mic in the $\mathrm{N}$, and Puturosul and Balvanyos in the E); (2) its morphology and size are similar to the main dacitic domes; (3) its phenocryst content (plagioclase, amphibole, biotite) is identical to that of the dacitic Ciomadul domes (with a slightly more mafic groundmass composition: Szakács and Seghedi 1986; Szakács et al. 2015); (4) according to the major element geochemistry of the andesite, it belongs to the same cluster of data points in the petrochemical diagrams (except the lower silica content) as the rest of the Ciomadul dome rocks (Szakács and Seghedi 1986); (5) there are mafic components in parts of the dacite dome rocks, such as pyroxene (Szakács and Seghedi 1986; Kiss et al. 2014) or even olivine (Kiss et al. 2014). A newly obtained (U-Th)/He zircon age of $842 \pm 53 \mathrm{ka}$ (Molnár et al. 2018) overlaps with the K-Ar age of $1.02 \pm 0.07 \mathrm{Ma}$ (i.e. $1020 \pm 70 \mathrm{ka}$; Szakács et al. 2015) at $2 \sigma$ level and confirms that Dealul Mare is one of the oldest domes of the whole Ciomadul-Puturosu area. On this basis, we use a minimum age of $\sim 850 \mathrm{ka}$ for the onset of the Ciomadul volcanism. representing an explosively disrupted dome. Other ages in gray refer to previous conventional K-Ar (Szakács et al. 2015) and zircon (U-Th)/He ages (Molnár et al. 2018). International highway E578 is marked in green, other national roads in blue frame. Red diagonal line marks the position of the cross-section in Fig. 3

The larger area of the chain terminus of the volcanic range (Fig. 2) is characterised by much older and extended volcanism, for which conventional K-Ar and (U-Th)/He ages are available. Dating of the adjacent Pilișca volcanic edifice in the NW has typically yielded older ages than Ciomadul, between 2.6-1.5 Ma (Pécskay et al. 1995; Szakács et al. 2015; Molnár et al. 2018). One of its probably youngest satellite domes, Dealul Babei (Bába Laposa), is dacitic in composition, and has been dated at $1.46 \pm 0.27 \mathrm{Ma}$ (Szakács et al. 2015) and $942 \pm 65 \mathrm{ka}$ (Molnár et al. 2018), close to the earliest constrained Ciomadul activity.

At the southernmost part of the volcanic range and to the west of river Olt, the two individual domes of Murgul Mare (Nagy Murgó: andesite) and Murgul Mic (Kis-Murgó: shoshonite), as well as the nearby Luget-Malnaș (LügetMálnás) shoshonite lava flows (Fig. 2), seem contemporaneous with the older part of Pilișca volcano. Murgul Mare was dated at $2.69 \pm 0.22 \mathrm{Ma}$ and $2.25 \pm 0.09 \mathrm{Ma}$ by Szakács et al. (2015), and at 1.86 \pm 0.08 Ma by Molnár et al. (2018), whereas the Malnas lava was dated at $2.22 \pm 0.14 \mathrm{Ma}$ by Peltz et al. (1987). Given the older ages and the predominantly different 
petrography compared with the Ciomadul dacites, the lava domes and flows of the southernmost part suggest a separate evolution and, as such, cannot be considered belonging to the Ciomadul volcanic system. Therefore, Murgul Mare (andesite) and Murgul Mic (shoshonite), along with the shoshonitic lava flows of Luget-Malnaş, are not included in our study.

The basement of the western part of the Ciomadul dacites reveals older andesites of the Pilişca volcano which crop out along the Olt riverbed in the Tuşnad Gorge. A drillcore down to $109 \mathrm{~m}$ in the andesite yielded a K-Ar age of $1.93 \pm 0.09 \mathrm{Ma}$ (Szakács et al. 2015). To verify the age of the basement on which the Ciomadul dacites were emplaced, we performed further two Cassignol-Gillot $\mathrm{K} / \mathrm{Ar}$ age determinations on the exposed andesites.

For the Ciomadul-Puturosu dacitic lava dome evolution, the rocks of the southeastern Puturosu dome are somewhat younger than Dealul Mare; they have been dated at $\sim 700 \mathrm{ka}$ by both the conventional (Szakács et al. 2015) and the Cassignol-Gillot K-Ar technique (Lahitte et al. this volume). A slightly younger age of $641 \pm 9 \mathrm{ka}$ has been obtained on the neighbouring Balvanyos dome (Lahitte et al. this volume), whereas another, much younger age of $440 \pm 12$ ka probably dates an adjacent dome (locality uncertain). In contrast to the younger, central domes, it is this relatively old Puturosu (meaning "stinky") area that shows the most intense $\mathrm{H}_{2} \mathrm{~S}$ bearing $\mathrm{CO}_{2}$ gas emissions at present (Szakács 2010; Kis et al. 2017).

Haramul Mic (Kis-Haram), which faces the wide alluvial plain of the Ciuc (Csíki) Basin, is the northernmost of the Ciomadul lava domes (Fig. 2). This flat-topped dome was considered previously as one of the oldest, eroded features of the whole lava dome complex and was dated at $0.85 \mathrm{Ma}$, i.e. similar to Dealul Mare (Pécskay et al. 1995; Szakács et al. 2015). However, it was also proposed that it is just a "low dome" in the sense of Blake (1989), being roughly contemporaneous with the main, central dome group (Karátson et al. 2013). Both the newly obtained $163 \pm 11 \mathrm{ka}(\mathrm{U}-\mathrm{Th}) / \mathrm{He}$ age (Molnár et al. 2018) and the $245 \pm 22$ ka Cassignol-Gillot KAr age (Lahitte et al. this volume) confirm that Haramul Mic is indeed significantly younger than the 700-800 ka old southern lava domes (Molnár et al. 2018; Lahitte et al. this volume).

Based on the new Cassignol-Gillot K/Ar groundmass age determinations, the emplacement of the Haramul Mic dome was followed by the satellite dome Vf. Cetăţii (Vár-tető) at $184 \pm 5 \mathrm{ka}$ and, subsequently, the main central dome complex consisting of the roughly coeval Vf. Comloș (Komlós-tetö) and Ciomadul Mare (Nagy-Csomád) domes dated at $144 \pm$ $4 \mathrm{ka}$ and $133 \pm 18 \mathrm{ka}$, respectively (Lahitte et al. this volume). After a possible short repose period, the eruptive activity at Ciomadul was followed by construction of the highly symmetrical dome of Haramul Mare (Nagy-Haram) at $96 \pm 2 \mathrm{ka}$ (Lahitte et al. this volume). The Ciomadul Mare domes (along with Vf. Comloş, and the not yet dated Vf. Surduc [Szurdoktetö] dome) represent the largest part of the central dome complex by volume.

Finally, the twin-crater morphology of Mohoș and St. Ana was created during the latest explosive phase of the second stage (Szakács et al. 1993; Szakács and Seghedi 1995; Karátson et al. 2013, 2016; Szakács et al. 2015). Karátson et al. (2013) proposed that the flat, uniform, arcuate northern lava dome rim of Ciomadul Mare (with its highest point at $1301 \mathrm{~m}$ a.s.1.) may be linked to a large pre-Mohoș craterforming eruption. This may have been followed by the formation of the Mohoș crater, associated with one of the so-called "Turia phreatomagmatic eruptions" (Karátson et al. 2016) dated at $\geq 50 \mathrm{ka}$. The Mohoş crater hosts a $\sim 60 \mathrm{~m}$-thick lacustrine/peat succession with a number of tephra units (Karátson et al. 2016; Wulf et al. 2016), the oldest of which are not yet dated. Dating of a crater rim dome or flow on the southern slopes, Piscul Pietros (Köves Ponk, Fig. 2), which is truncated by the crater morphology, yielded a K-Ar age of 60 $\pm 5 \mathrm{ka}$ (Lahitte et al. this volume), in contrast to earlier published K-Ar ages of around 0.5 Ma (Pécskay et al. 1995; Szakács et al. 2015). Such a morphological relationship places the final explosive phase at younger than $60 \mathrm{ka}$. In this paper, to confirm the age relationship of the Mohoş crater and its surrounding lava domes, new K-Ar dating was conducted on another rim dome in the north, Vf. Mohoș (Mohos-tetö).

The final eruptions of Ciomadul originated from the circular-shaped St. Ana explosion crater that cuts the Mohoș crater rim. Two subsequent explosive eruptions labelled as "TGS" (a plinian or subplinian eruption sequence named after the town of Târgu Secuiesc) and "LSPA" (Latest St. Ana phreatomagmatic activity) may have been related to the final crater formation (Karátson et al. 2016, 2017; Wulf et al. 2016). Of these, LSPA might have occurred at $\sim 29 \mathrm{ka}$ on the basis of ${ }^{14} \mathrm{C}$ ages obtained from both the lower part of the sediment infill of St. Ana crater lake (Magyari et al. 2014) and the upper part of the Mohoș lacustrine succession (Karátson et al. 2016; Wulf et al. 2016). The present-day St. Ana crater rim reveals fragmented but massive fresh lava dome blocks, which occur in particular on the southern crater slopes and are presumably of LSPA age. Apart from the $60 \pm 5$ ka Piscul Pietros lava dome (or coulée), there is no other original dome landform nearby with which these blocks can be correlated. Therefore, the exposed rocks might correspond to an explosively disrupted dome in the vicinity, possibly related to St. Ana crater. Cassignol-Gillot K-Ar dating was applied on one of the scattered blocks to constrain this terminal volcanic activity.

The lava domes of Ciomadul are in some cases surrounded by the original breccia apron (Szakács et al. (2015). The apron includes some dacite lava flows (up to 5-6-km long) sourced from the domes (Szakács et al. 2015). However, the majority of the apron also includes finer grained volcaniclastic 
deposits, including outwash sheets, debris-flow deposits, and minor block-and-ash flow deposits (cf. Santiaguíto: Rose 1987). A part of these accumulated during the eruptive stages, but significant reworking might have contributed to the aprons post-eruptively, during the Last Glacial Maximum, when the vegetation at Ciomadul was sparse and erosion intensified (Magyari et al. 2014). Erosion certainly reduced the volume of the original domes to some extent, but the eroded material may have largely been added to the apron volume (cf. Kuenzi et al. 1979). More distal volcaniclastic deposits, which are poorly constrained, also occur in the Ciuc Basin to the north of Ciomadul, as well as along the margins of the southernlying Bodoc (Bodok) and Turia (Torjai) Mountains. However, as Szakács et al. (2015) stated, overall the lava dome shapes show only insignificant post-eruptive erosional overprint.

It should also be noted that the margins of the domes as well as the topographic lows in between the domes (in particular on the eastern and southern flanks of the edifice) are in some places covered or draped by the pyroclastic deposits of the latest explosive phase (Szakács et al. 2015, Karátson et al. 2016). The volume of the pyroclastic deposits has not yet been assessed, but their contribution to Ciomadul is negligible.

\section{DEM-based volumetry}

\section{Methodological issues}

Volumetrical time inventories of volcanic edifices can be determined at different spatial and temporal scales ranging from regional tectonic/erosional studies (e.g. Stoiber and Carr 1973; White et al. 2006; Karátson et al. 2012) to those considering fast and occasionally $\mathrm{m}$-scale topographic changes occurring at active volcanoes (e.g. Fornaciai et al. 2012; Favalli et al. 2010; Diefenbach et al. 2013). Previously, volumetrical (and other morphometrical) studies simply used topographic map data (Pike and Clow 1981), but since the advent of digital elevation models (DEM) with worldwide (SRTM, ASTER) or regional (e.g. US NED, TINITALY) coverage, the procedure of landform delimitation or volume calculation has become more accurate. A number of recent volumetrical studies have resulted including those covering small monogenetic landforms such as scoria cones (e.g. Favalli et al. 2009; Bemis et al. 2011; Kereszturi and Németh 2012; Kervyn et al. 2012; Bemis and Ferencz 2017) and lava domes (Lahitte et al. 2012; Karátson et al. 2013; Nomikou et al. 2014), as well as large polygenetic landforms such as composite (e.g. Grosse et al. 2009; Karátson et al. 2010b; Lavigne et al. 2013; Germa et al. 2015; Ricci et al. 2015) and shield volcanoes (e.g. Germa et al. 2010; Salvany et al. 2012; Pedersen and Grosse 2014; Grosse and Kervyn 2018). However, relatively few papers discuss the possible error factors of volume calculations. Examples include Bohnenstiehl et al. (2012) who presented how the cone volume calculated by the closed-contouring algorithm changes with respect to the regional slope value and the contour search intervals. These authors found that the volume of low ( 100 -m high) cones might be underestimated by $30-50 \%$ if the basal surface is sloping $\left(2^{\circ}\right)$ or the contour interval is relatively large $(20 \mathrm{~m})$, and suggested a modified algorithm that takes into account the local slope when the edifice is outlined. Kereszturi and Procter (2016) showed how the calculated eruptive volumes of monogenetic volcanoes are sensitive to the input data type and their spatial resolution.

As discussed in detail for small landforms by Favalli et al. (2009) and Kereszturi et al. (2013), and for larger edifices by Grosse et al. (2012), the precision of volume calculation largely depends on the appropriate delimitation of volcano boundaries and the related basal surface. Defining the boundary of any volcano might be complicated by the diverse, often compound architecture of the volcanic terrain (e.g. disturbed boundaries with adjacent, sometimes superimposed volcanoes and/or surrounding landscape, far-reaching volcanic products, such as long lava flows, and tilted basal surfaces). However, constructional landforms (e.g. composite and shield volcanoes, as well as individual domes and cones), which have a positive topography, are commonly bounded by concave breaks in slope, a feature which is used to define the boundaries in most DEM-based studies (Karátson and Timár 2005; Favalli et al. 2009; Grosse et al. 2012; Karátson et al. 2012). In particular, Grosse et al. (2009) and Euillades et al. (2013) derived automated methods for a more objective boundary definition.

As a result of such advances, volume calculation is now a routine task if the required input parameters, such as appropriate data from regional geology, field mapping, and DEM coverage, are available. DEM data provided by the SRTM data base with 3" ( $\sim 90 \mathrm{~m}$ spatial resolution) was found sufficient for composite and shield volcanoes (e.g. Karátson and Timár 2005; Kervyn et al. 2008; Karátson et al. 2010b, 2012; Lavigne et al. 2013), whereas higher spatial resolution DEMs are required for studying smaller monogenetic landforms such as scoria cones (Fornaciai et al. 2012). Small surface changes on active volcanoes can be studied preferably by LiDAR or photogrammetry-based with a $2-5 \mathrm{~m}$ resolution (Fornaciai et al. 2010).

From a methodological point of view, general issues for volume calculations of the lava domes of the Ciomadul area include

1) Data resolution.

2) The method of numerical integration ("rectangular rule" versus "trapezoidal rule" versus "Simpson's rule").

3) Horizontal landform delimitation.

4) The accuracy of the base level (Yanalak and Baykal 2003; Grosse et al. 2012). 
In regard to point (2), all three of these methods use cellbased right prisms to calculate the volume, but in the rectangular case the prism top is flat, in the trapezoidal case the prism top is oblique, and in the Simpson case, the prism top is a parabolic surface, which provides a better approximation of the real surface (Press et al. 1988). For point (4), determining the appropriate base level of a given volcano raises several problems, such as the need for information on bedrock, the presence of subvolcanic bodies above or below the basement contact, or the role of tectonic faults.

In order to quantify the error magnitudes attributed to all of these factors, we carried out test volume calculations on some volcanic landforms including small (lava domes) and large (composite volcanoes) edifices, using data from Telbisz et al. (2017). We incrementally changed the spatial resolution, the outlined boundary and the base level of the target landforms, and used different methods of volume calculation to assess the effect of spatial resolution, the integration method, the horizontal delimitation and the base level, on the final result (see Table 4 in Appendix). Our comparison based on 1/9" ( 3m), 1/3" ( 10 m) LiDAR, 1" ( 30m) and 3" ( 90 m) SRTM data shows that in most cases the volumes can be appropriately calculated by using SRTM 1" or even SRTM $3 "$. Namely, the average of volume differences between SRTM 1" and the best available spatial resolution dataset is only $2.8 \%$. The integration method of volume calculation (rectangular versus trapezoidal; Simpson's rule vs trapezoidal) yields a negligible difference, which is generally less than $1 \%$.

On the other hand, delimitation of the horizontal boundaries has a more important effect on the volume; we found that $1 \%$ variation in the average edifice radius introduces an average error of $0.8 \%$ in terms of volume. In the case of field-based studies (i.e. when reliable geological maps are available), the error of the average edifice radius may be in the $1-5 \%$ range, thus the resultant error on volume is less than $4 \%$.

Finally, the most critical factor is the base level. If the volcano is built up on a flat surface, then interpolating the level of the terrain surrounding the edifice can provide a good approximation. If the basement topography is undulating or complicated, and there are no surface outcrops or borehole data to infer the surface geometry of the bedrock, geophysical data and/or appropriate analogues are required (cf. Kereszturi et al. 2013). For instance, using a theoretical approach, error (dV) of volume estimation (V) of a pure cone-shaped volcano (having a slope of $\alpha$ ) due to error $(\mathrm{dh})$ in height measurement $(\mathrm{h})$ yields a relative error in volume:

$\mathrm{dV} / \mathrm{V}=\left(\pi \cdot \operatorname{ctg}^{2}(\alpha) \cdot \mathrm{h}^{2} \cdot \mathrm{dh}\right) /\left(\pi \cdot \operatorname{ctg}^{2}(\alpha) \cdot \mathrm{h}^{3} / 3\right)=3 \mathrm{dh} / \mathrm{h}$

where cotangent function is the reciprocal of tangent $(\operatorname{tg})$.
This represents, for instance, a relative error of $10 \%$ for a difference of $10 \mathrm{~m}$ at the base level of a 300-m-high volcano. Based on calculations of worldwide volcanic edifices (Telbisz et al. 2017), the base level error is $1 \%$ of the height, and the inferred volumetrical error is, on average, $6.1 \%$. Admittedly, the base level uncertainty may exceed $1 \%$, if the basement is not constrained by field evidence. Therefore, field constraints on the base level have been considered a crucial issue in our study if we are to obtain precise volumes.

At Ciomadul, the boundaries of the individual lava domes were determined using the geological maps of Szakács and Seghedi (1990, 1995), Szakács et al. (2015), and the volcanogeomorphological map of Karátson et al. (2013). Dome boundaries were field-checked in spring 2017, adding GPSfixed points of those surface outcrops where the boundary could be observed. Observations included lava flow and talus breccia outcrops in heavily vegetated surfaces, contacts between Ciomadul dome breccias and underlying Pilișca andesites, or flysch exposures. The modified extent of the lava domes and flows are depicted on an updated volcanogeomorphological map of Ciomadul (as given in Fig. 2).

\section{Base level considerations}

The northern apron northwest of Haramul Mic in particular suggests that lava flows reached the Olt river valley at the village of Tusnad Nou (Újtusnád). Although the precise areal extent is impossible to outline, the northernmost lava outcrop cut by the river can be connected southward to local hummocks (locally called "ponks"), which are interpreted here as isolated, eroded original lava surfaces (further sculpted by long-term agricultural activity). Based on their position, a lava flow direction from the south can be assumed, i.e. from Haramul Mare or perhaps Haramul Mic (Fig. 2). In addition, according to our field inspection, both Haramul Mare and, especially, Haramul Mic have larger, extended talus breccia aprons, in some places covering the proximal lava flows.

To the west, the Ciomadul dacites directly overlie older andesites of the adjacent Pilişca (Piliske) volcano in the South Harghita Mountains (Szakács et al. 2015). These andesites crop out at numerous sites between 610 and $650 \mathrm{~m}$ elevation along the Olt riverbed which is deeply incised in the Tuşnad gorge. The obtained elevations were taken here as defining the basal surface for the dacitic volcanism of Ciomadul.

In the east, the boundary of the uplifted Cretaceous flysch rocks, already indicated by Szakács and Seghedi (1990), has been confirmed by measuring outcrops with GPS in some deeply incised stream and road cuts. The flysch is exposed commonly at around 700-800 $\mathrm{m}$ a.s.l., but at the elevated Bolondos Hill, as high as at $980 \mathrm{~m}$ a.s.l. In the southeast, in contrast to the published volcanological map (Szakács and Seghedi 1990), the Piscul Pietros lavas flowed farther to the 
south, directly overlying both the flysch exposed along the stream of Paraul Jimbor (Zsombor stream) and the older andesites of Dealul Mare at $\sim 780-790$ m a.s.l. Taking all these additional data into consideration, the basal boundary polygon of Ciomadul has a lowermost point at $579 \mathrm{~m}$, a highest point at $980 \mathrm{~m}$ and an average elevation of $704 \mathrm{~m}$.

On the basis of the geological cross sections given in Szakács and Seghedi (1990), the interpolation between the underlying western (Pilişca) andesites and the eastern flysch defines a "pre-Ciomadul" surface, which slightly dips toward the present-day Olt river (Fig. 3). On the DEM, this surface was created by filling the outlined dome area by natural neighbour interpolation. The interpolated surface has an average elevation of $714 \mathrm{~m}$ a.s.l., very similar to the $704 \mathrm{~m}$ determined from the surface polygon boundary. The interpolated surface indicates a relatively wide valley or basin, which likely existed prior to the volcanic activity. This dipping surface was taken as the pre-Ciomadul basal surface instead of a flat, constant base level.

Individual dome volumes (Table 1) were calculated using the superficial boundary of each dome extended by a gently dipping $\left(<5^{\circ}\right), 100-500 \mathrm{~m}$ wide apron based on the volcanological map of Szakács and Seghedi (1990) and our own field observations. To calculate the gradual increase of erupted magma volumes during the evolution of the dome complex, we reconstructed DEMs of the successive dome-building stages. Starting from the basal surface, individual domes with their aprons were added to the DEM step by step, following an order defined by their respective ages. Erosional changes between subsequent domes were considered negligible in relation to their dominantly young, $<200 \mathrm{ka}$ age and an overall $31.5 \mathrm{~m} / \mathrm{My}$ denudation rate obtained for the larger area (Karátson 1996). Volumes of individual lava domes (or coalesced lava dome groups) were calculated from DEM differences between two subsequent stages. Thus, we did not use a constant base level but an updated topography in each step. The volume calculation method used was the trapezoidal rule.

\section{Sequence of volume calculations}

The temporal evolution, defined by the successive growth of individual lava domes, has been constrained using the new Cassignol-Gillot K-Ar dates (as is given in Table 1). The age of Vf. Surduc (Szurdok-tetö), which was not determined, has been tentatively placed between Vf. Cetății and Vf. Comloș on the basis that its position is in between the latter two. Within Table 1, a number of domes (e.g. Ciomadul Mare, Haramul Mare) consist of extrusions from more than one vent (they thus represent compound domes such as Soufriére Hills, Montserrat: Hale and Wadge 2008); however, without detailed ages, their emplacement histories cannot be further subdivided.

\section{Results}

The resulting total volume of the entire Ciomadul edifice is 7.82 $\pm 0.41 \mathrm{~km}^{3}$ (Table 1). About $80 \%$ of this volume $\left(6.25 \mathrm{~km}^{3}\right)$ belongs to the lava domes themselves (note that all estimates here are bulk rock), whereas the remaining $20 \%\left(1.57 \mathrm{~km}^{3}\right)$ includes the undifferentiated volcaniclastic material forming the surrounding aprons. Individual dome volumes, in the case of the simple landforms which could have been determined, are on the order of $0.1-0.4 \mathrm{~km}^{3}$, i.e. $\sim 3-6 \%$ of the whole lava dome complex. Some minor domes (e.g. Balvanyos, Mohoș) have even smaller volumes $\left(0.02-0.1 \mathrm{~km}^{3}\right)$. The two largest coalesced lava domes (Ciomadul Mare and Haramul Mare) have a volume of $4.1 \mathrm{~km}^{3}$ ( $\sim 53 \%$ of the whole complex).

Erosion has affected the original erupted volumes. We have already noted that the talus breccias are mostly related to synvolcanic redeposition, likely enhanced by post-eruptive
Fig. 3 SRTM DEM-based crosssection through Vf. Comloș and Ciomadul Mare with main geological features, showing the gently dipping $\left(<5^{\circ}\right)$ basement consisting of $\sim 2 \mathrm{Ma}$ andesites (marked with $\alpha$ ) and Cretaceous flysch. Coordinates in UTM zone $35 \mathrm{~N}$. For the position of section, see Fig. 2

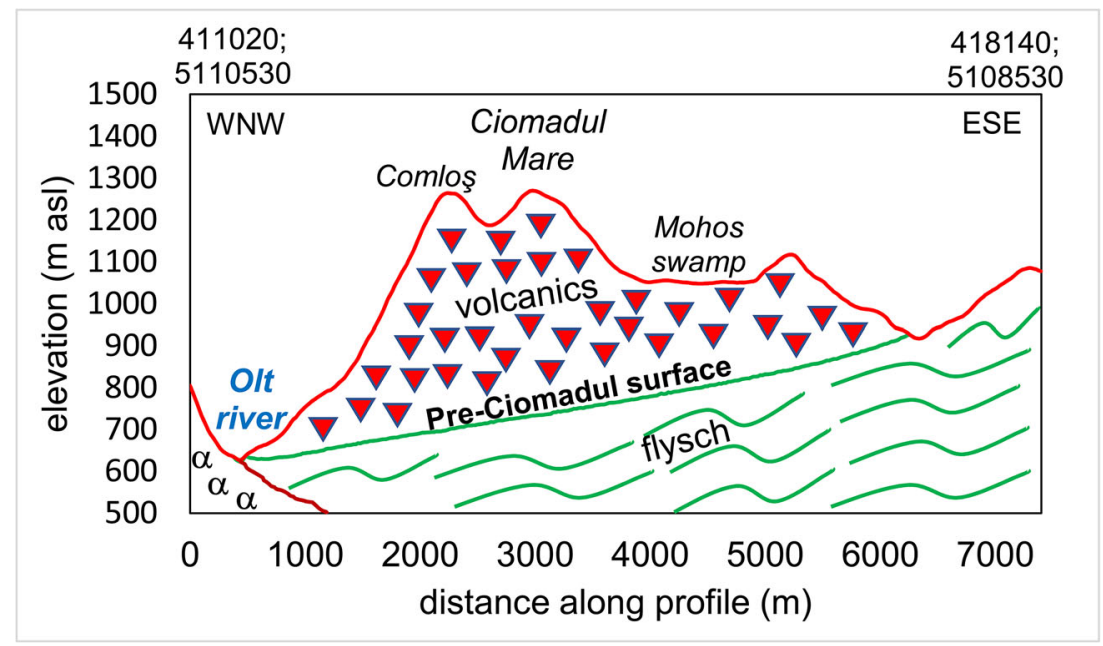


Table 1 Volumetry and age constraints of the Ciomadul lava domes

\begin{tabular}{|c|c|c|c|c|c|c|c|}
\hline & $\begin{array}{l}\text { Cassignol } \\
\text { K-Ar age }(\mathrm{ka})^{1,2}\end{array}$ & $\begin{array}{l}(\mathrm{U}-\mathrm{Th}) / \mathrm{He} \\
\text { age }(\mathrm{ka})^{3}\end{array}$ & $\begin{array}{l}\text { Base level } \\
(\mathrm{m} \text { asl) }\end{array}$ & $\begin{array}{l}\text { Area } \\
\left(\mathrm{km}^{2}\right)\end{array}$ & $\begin{array}{l}\text { Present } \\
\text { Volume }\left(\mathrm{km}^{3}\right)\end{array}$ & $\begin{array}{l}\text { Proportional } \\
\text { volume } \\
\text { (as \% of total) }\end{array}$ & $\begin{array}{l}\text { Erosion since } \\
\text { emplacement } \\
\left(\mathrm{km}^{3}\right)^{* * *}\end{array}$ \\
\hline Dealul Mare (Hegyes-tető) & - & $842 \pm 53$ & 760 & 1.52 & $0.30 \pm 0.03$ & $3.9 \%$ & 0.040 \\
\hline Puturosu (Büdös) & $704 \pm 18^{1}$ & $642 \pm 44$ & 900 & 0.47 & $0.07 \pm 0.01$ & $0.9 \%$ & 0.010 \\
\hline Balvanyos (Bálványos) & $641 \pm 9^{1}$ & $583 \pm 30$ & 870 & 0.20 & $0.02 \pm 0.00$ & $0.3 \%$ & 0.004 \\
\hline Haramul Mic (Kis-Haram) & $245 \pm 24^{1}$ & $163 \pm 11$ & 690 & 1.34 & $0.19 \pm 0.03$ & $2.4 \%$ & 0.010 \\
\hline Vf. Cetății (Vár-tető) & $184 \pm 5^{1}$ & - & 684 & 1.05 & $0.29 \pm 0.02$ & $3.8 \%$ & 0.006 \\
\hline Vf. Surduc (Szurdok-tető) & $164 *$ & - & 651 & 1.28 & $0.39 \pm 0.02$ & $5.0 \%$ & 0.007 \\
\hline Vf. Comloș (Komlós-tető) & $144 \pm 4^{1}$ & - & 660 & 0.79 & $0.43 \pm 0.03$ & $5.5 \%$ & 0.004 \\
\hline Ciomadul Mare (Nagy-Csomád) & $133 \pm 18^{1}$ & - & 616 & 7.96 & $2.90 \pm 0.15$ & $37.1 \%$ & 0.033 \\
\hline Haramul Mare (Nagy-Haram) & $96 \pm 2^{1}$ & - & 725 & 3.86 & $1.20 \pm 0.08$ & $15.4 \%$ & 0.012 \\
\hline Vf. Mohoș (Mohos-tető) & $64 \pm 2^{2}$ & - & 812 & 1.02 & $0.10 \pm 0.02$ & $1.3 \%$ & 0.002 \\
\hline Piscul Pietros (Köves Ponk) & $60 \pm 5^{1}$ & - & 775 & 1.14 & $0.34 \pm 0.03$ & $4.3 \%$ & 0.002 \\
\hline Volcaniclastic aprons & $28 * *$ & - & & 53.81 & $1.57 \pm 0.13$ & $20.1 \%$ & 0.044 \\
\hline Total & & & & 74.44 & $7.82 \pm 0.55$ & $100 \%$ & 0.175 \\
\hline
\end{tabular}

${ }^{1}$ Cassignol-Gillot K-Ar age of lava dome rock obtained on groundmass or (for Haramul Mic and Ciomadul Mare) plagioclase microlite: Lahitte et al. (this volume)

${ }^{2}$ Cassignol-Gillot K-Ar age of lava dome rock obtained on groundmass (this work)

${ }^{3}$ (U-Th)/He age of zircon crystals separated from lava dome rock: Molnár et al. (2018)

*Averaged from Vf. Cetății and Vf. Comloș

**Considered as if the whole volume of the surrounding volcaniclastics had been deposited after the last eruption

***Calculating with a long-term erosion rate of $31.5 \mathrm{~m} / \mathrm{My}$ (Karátson 1996) applied to each dome area

Uncertainties of the present volumes are calculated by using formula (1) assuming $10 \mathrm{~m}$ error in base level

erosion. In contrast, at present, debris-flow activity or significant slope wash processes are not observed; a result from thick vegetation cover. In accordance with this, fluvial dissection of the area is also minor due to the young age of volcanism as well as the protective soil and vegetation cover. Field observations confirm that individual or coalesced domes tend to preserve their original shape. The erosionally removed material has fed the weakly evolved drainage network, which transports sediments to the neighbouring basins and the Olt river system (Bányai 1917, 1964; Bulla 1948; Fielitz and Seghedi 2005).

By aggregating periods with low versus high erosion, the volume of the material removed by erosion during the whole life time of Ciomadul can be estimated using the area-specific long-term erosion rate (surface lowering) estimate of $31.5 \mathrm{~m} /$ My, which was proposed for the study area using comparative morphometry (Karátson 1996). This rate is an average figure over the Northeast and East Carpathians, integrating a ca. 10 My period with multiple climatic changes. Numerically, this rate is in agreement with values derived by various methods for temperate continental climates (Saunders and Young 1983; Summerfield 1991). We calculated eroded volumes separately for each dome by using the average $31.5 \mathrm{~m} / \mathrm{My}$ erosion rate, and the area and age of each dome (Table 1). Obviously, the error of the eroded volume is larger for the younger domes due to the fact that the applied erosion rate is long term; however, the magnitude of the overall erosion volume is reliable. The individual eroded volumes give a combined total of $0.18 \mathrm{~km}^{3}$ erosion for the whole Ciomadul-Puturosu Hills over the past $\sim 850 \mathrm{ky}$. Adding this figure to the present-day volumes, the total original volume of the lava dome complex is proposed to have been $8.00 \pm 0.55 \mathrm{~km}^{3}$. This means that the erosionally removed volume has been insignificant equating only to $2.2 \%$ of the total dome volume.

Obviously, such a calculated erosion figure is considered a minimum estimate. On one hand, short-term post-eruptive erosion rates, due, for instance, to unvegetated surfaces, are generally higher than long-term rates (cf. Santiaguíto: Harris et al. 2006). As at Santiaguíto, the presence of areally significant volcaniclastic deposits may have also enhanced erosive processes in some proximal places. Nevertheless, given the little proportion of the eroded volume calculated, these uncertainties make no difference relative to the main results obtained on the volumetry of the volcanic activity.

\section{Cassignol-Gillot K-Ar dating}

To constrain the time interval during which Ciomadul's volcanism developed, the minimum age of the basement on which Ciomadul dacites were emplaced, and the age of the 
volcano's latest activity, need to be known. Four selected lava samples, the localities of which are described above, were dated using the Cassignol-Gillot K-Ar technique in the Laboratoire GEOPS at Paris-Sud University, Orsay, France (Table 2). Full details of the analytical procedure are given in the accompanying study (Lahitte et al. this volume) as well as in the Supplement. The obtained ages presented here complement the nine new ages included in Lahitte et al. (this volume) and serve as the basis for magma output rate calculations.

Located along the riverbed of the Olt in the southern part of Tuşnad Gorge, two samples from andesitic lava flows (17EC12 and 17EC13), attributed to Pilișca volcano and directly overlain by Ciomadul's dacite lava, were dated at 2130 $\pm 30 \mathrm{ka}$ and $2110 \pm 30 \mathrm{ka}$, respectively. Such ages, within $2 \sigma$ error, match the $1.93 \pm 0.09 \mathrm{Ma}$ conventional $\mathrm{K}-\mathrm{Ar}$ age (Szakács et al. 2015) obtained on drillcore samples in the same area. The confirmed old age implies that the topographic level on which Ciomadul was emplaced can be considered palaeogeographically as an erosional surface, formed during the ca. 1 My-long time gap preceding Ciomadul's activity.

The sample of the lava dome of Vf. Mohoș (16CIO05) yielded a well-constrained age of $63.9 \pm 1.6 \mathrm{ka}$ (Table 2). This age, within $2 \sigma$ uncertainty, is the same as that of the Piscul Pietros dome or flow $(60 \pm 5 \mathrm{ka})$. One of the scattered dacite lava blocks (sample 16CIO11), draping the southern slope of St. Ana crater, yielded an age of $27.7 \pm 1.4 \mathrm{ka}$. In order to precisely constrain this latest activity, we performed five measurements of different aliquots of the same sample (Table 2). As described above, the exposed blocks may correspond to an extrusive phase, which is correlated, by their position, to one of the final Ciomadul eruptions, possibly the one that excavated the present-day St. Ana crater. The K-Ar age obtained is the youngest measured by direct dating of Ciomadul rocks and, compared with other dating results (e.g. Harangi et al. 2015; Szakács et al. 2015; Karátson et al. 2016), confirms that it can be taken as evidence of the latest activity of the volcanic edifice.

\section{Discussion}

\section{Dome volumetry at Ciomadul: a worldwide comparison}

Andesitic-dacitic lava domes vary highly in volume from $\leq$ 0.01 to $\sim 30 \mathrm{~km}^{3}$. In Table 3 , examples of some of the bestknown andesitic-dacitic domes are given. Probably the largest dome, the Late Pleistocene Chao dacitic coulée (Chile), which is related to the Cerro del León stratovolcano (de Silva et al. 1994), has a volume of $26 \mathrm{~km}^{3}$, comparable with mediumsized stratovolcanoes. It was emplaced over an area of $>$ $50 \mathrm{~km}^{2}$. The post-caldera activity at Yellowstone caldera produced even larger-volume individual silicic lava units, such as the $72 \mathrm{ka}$ rhyolitic Pitchstone Plateau of $70 \mathrm{~km}^{3}$ (Christiansen et al. 2007), but these are flows rather than domes. However, rhyolitic domes can also be exceptionally large, such as the 7.3 ka submarine dome at Kikai caldera, Japan, which has a volume of $32 \mathrm{~km}^{3}$ (Tatsumi et al. 2018). Another large dacitic dome, the Nevado del Toluca summit dome complex (Mexico), which formed within the past $50 \mathrm{ky}$, has a volume of $11 \mathrm{~km}^{3}$ (Capra et al. 2015).

Examples of medium-sized lava domes include Santiaguíto (Guatemala), where four adjacent domes and flows have been extruded since 1922 (Harris et al. 2003), or the 1951 lava dome of Mt. Lamington in Papua New Guinea (Taylor 1958), both with ca. $1 \mathrm{~km}^{3}$ total volume. Similarly, the eruption of the Soufriére Hills dome complex (Montserrat) resulted in a total volume of $1 \mathrm{~km}^{3}$ between 1995 and 2009, the dome being constructed in four phases with lobes of $0.1-0.3 \mathrm{~km}^{3}$ in volume (Wadge et al. 2010; Ryan et al. 2010). At Unzen volcano, Japan, during the 1991-1993 eruption, a total dome volume of $0.2 \mathrm{~km}^{3}$ was extruded (Nakada et al. 1999).

On the other hand, individual dome-forming events often produce much smaller, overlapping domes or flows, such as the andesitic dome of M. Pelée, Martinique (1902) with a summit plug of $0.01 \mathrm{~km}^{3}$ (Boudon et al. 2015), or the dacitic intracaldera dome of Mt. St. Helens (1980) also with a volume of $0.01 \mathrm{~km}^{3}$

Table 2 K-Ar ages obtained on groundmass of Pilișca-type andesites and selected Ciomadul dacites

\begin{tabular}{|c|c|c|c|c|c|c|}
\hline Sample code, locality name & $\mathrm{K} \%$ & $\begin{array}{l}{ }_{\%}^{40} \mathrm{Ar}^{*} \\
\end{array}$ & $\begin{array}{l}{ }^{40} \mathrm{Ar}^{*} \\
\left(\times 10^{11} \mathrm{at} / \mathrm{g}\right)\end{array}$ & $\begin{array}{l}\text { Age } \pm 1 \sigma \\
(\text { in ka) }\end{array}$ & $\begin{array}{l}\text { Weighted mean } \\
\text { age } \pm 1 \sigma(\text { in } \mathrm{ka})\end{array}$ & $\begin{array}{l}\text { Relative } \\
\text { uncertainty }\end{array}$ \\
\hline $17 \mathrm{EC} 12$ & \multirow[t]{2}{*}{0.592} & 19.65 & 13.24 & $2142 \pm 32$ & \multirow[t]{2}{*}{$2130 \pm 30$} & \multirow[t]{2}{*}{$1.5 \%$} \\
\hline Olt riverbed andesite & & 20.83 & 13.10 & $2118 \pm 32$ & & \\
\hline $17 \mathrm{EC} 13$ & \multirow[t]{2}{*}{0.599} & 13.90 & 13.40 & $2139 \pm 43$ & \multirow[t]{2}{*}{$2110 \pm 30$} & \multirow[t]{2}{*}{$1.6 \%$} \\
\hline Olt riverbed andesite & & 17,20 & 13.06 & $2086 \pm 43$ & & \\
\hline $16 \mathrm{CIO} 05$ & \multirow[t]{2}{*}{3.845} & 3.92 & 2.531 & $63.0 \pm 1.8$ & \multirow[t]{2}{*}{$63.9 \pm 1.6$} & \multirow[t]{2}{*}{$2.6 \%$} \\
\hline Vf. Mohoș dacite & & 5.87 & 2.590 & $64.5 \pm 1.4$ & & \\
\hline $16 \mathrm{CIO} 11$ & \multirow[t]{5}{*}{3.624} & 0.86 & 1.058 & $28.0 \pm 3.3$ & \multirow[t]{5}{*}{$27.7 \pm 1.4$} & \multirow[t]{5}{*}{$5.1 \%$} \\
\hline St. Ana crater rim & & 0.82 & 0.973 & $25.7 \pm 3.2$ & & \\
\hline southern flank dacite (block) & & 0.90 & 1.021 & $27.0 \pm 3.0$ & & \\
\hline & & 0.88 & 1.044 & $27.6 \pm 3.2$ & & \\
\hline & & 0.98 & 1.155 & $30.5 \pm 3.1$ & & \\
\hline
\end{tabular}


Table 3 Volumes of selected worldwide andesitic-dacitic lava domes

\begin{tabular}{llll}
\hline Lava dome & Lithology & Volume $\left(\mathrm{km}^{3}\right)$ & Reference \\
\hline Chao (Late Pleistocene) & Dacite & 26 & de Silva et al. 1994 \\
Nevado de Toluca & Dacite & 11 & Capra et al. 2015 \\
Santiaguíto (1922) & Dacite & 1 & Harris et al. 2003 \\
Soufriere (1995-2009) & Andesite & 1 & Wadge et al. 2010 \\
Unzen (1991-1993) & Dacite & 0.2 & Nakada et al. 1999 \\
Usu (1944) & Dacite & 0.02 & Yokoyama 2005 \\
Tarumai (1909) & Andesite & $0.01-0.02$ & Yokoyama 2005 \\
Merapi (2006) & Andesite & $\sim 0.01^{*}$ & Carr et al. 2016 \\
Mt. St. Helens (1980) & Dacite & $<0.01$ & Scott et al. 2008 \\
Mt. St. Helens (2005) & Dacite & $<0.01$ & Scott et al. 2008 \\
Pelée (1902) & Andesite & $<0.01$ & Boudon et al. 2015 \\
Novarupta (1912) & Dacite & 0.005 & Hildreth and Fierstein 2012 \\
\hline
\end{tabular}

*Published volume of $0.0084 \mathrm{~km}^{3}$ in Carr et al. (2016) refers to extruded magma in total
(Scott et al. 2008). During one of the current dome-forming episodes (2006) of the basaltic andesite dome complex of Merapi, consisting of dome growth and collapse events (Charbonnier and Gertisser 2008), a total extruded magma volume of $\sim 0.01 \mathrm{~km}^{3}$ was estimated (Carr et al. 2016). The 1912 eruption of Novarupta produced a small dome only $0.005 \mathrm{~km}^{3}$ in volume (Hildreth 1983; Yokoyama 2005).

According to our volumetrical results, Ciomadul, with its reconstructed total volume of $\sim 8 \mathrm{~km}^{3}$ spread over an area of $\sim$ $75 \mathrm{~km}^{2}$, belongs to the medium-sized lava dome complexes. However, the dimensions of most individual Ciomadul domes, where morphology allows distinct dome shape determination, are in the range of $0.1-0.4 \mathrm{~km}^{3}$, similar to those at Santiaguíto, Mt. Lamington and Soufrière Hills. Such a finding makes it likely that those parts of the edifice where individual domes cannot be distinguished also grew by superimposed or amalgamated domes (apart from the scattered peripheral domes of Ciomadul in the NW, $\mathrm{N}$ and SE).

\section{Assessment of erosion rates}

When calculating the original dome volumes, it is important to assess how much material has been removed by erosion (e.g. Karátson 1996; Bemis et al. 2011). In a previous attempt at Ciomadul, Karátson and Timár (2005) considered the volcano volumes along the whole East Carpathians. They included Murgul Mare and Murgul Mic in the Ciomadul-Puturosu area (which, as we stated above, do not belong to Ciomadul), and calculated a total volume of $15.3 \mathrm{~km}^{3}$, including erosional removal of $3.1 \mathrm{~km}^{3}$. If we extract the volume of Murgul Mare and Murgul Mic and their aprons (ca. $2 \mathrm{~km}^{3}$ ) as well as the $3.1 \mathrm{~km}^{3}$ of eroded material, the result is $10 \mathrm{~km}^{3}$, roughly comparable with the $7.82 \mathrm{~km}^{3}$ obtained in this study. However, Karátson and Timár (2005) overestimated the eroded volume $\left(3.1 \mathrm{~km}^{3}\right.$ versus $0.18 \mathrm{~km}^{3}$ obtained here). This is because the approach of
Karátson and Timár (2005) for calculating erosionally removed volumes was to "fill" valleys by surface envelopes using representative cross sections of the individual volcanic edifices. Whereas this method is correct for large, deeply dissected edifices and provides reliable results for other parts of the East Carpathians, it exaggerates the erosion rate for Ciomadul which shows only minor or no fluvial dissection.

Erosion in the Ciomadul-Puturosu area was relatively significant only for the oldest southeastern domes (Dealul Mare, Puturosu and Balvanyos). At Puturosu, even the vent part of the dome is partly exposed, related likely to the significant uplift of the Cretaceous flysch and associated accelerated erosion. By contrast, the even older Dealul Mare dome, due probably to its lower position, still preserves a regular dome shape showing apparently little erosion.

Szakács et al. (2015) presented a total volume of $8.74 \mathrm{~km}^{3}$ for Ciomadul (including the southern peripheral domes but without erosionally removed material), which is very similar to our calculations. However, in some cases, their individual dome volumes (see Table 4 in Szakács et al. 2015) are significantly larger than our estimates as listed in Table 1. For example, for Dealul Mare, Szakács et al. (2015) estimate 0.57 versus $0.30 \mathrm{~km}^{3}$ of this work; for Haramul Mic, the difference is 0.34 versus $0.19 \mathrm{~km}^{3}$; and for Puturosu, 0.17 versus $0.07 \mathrm{~km}^{3}$.

\section{Time-averaged magma output rates-implications for long-term lava dome growth}

On the basis of the volumetrical results (Table 1) and the new geochronological data (Tables 1, 2), time-averaged magma output rates of Ciomadul can be calculated. Certainly, obtaining such rates depends on the number of available radiometric ages and their resolution. The thirteen new $\mathrm{K}-\mathrm{Ar}$ ages obtained here do not yield constraints to calculate 
eruption-scale extrusion rates, but can be used to infer longterm evolutionary trends of Ciomadul in a worldwide context.

The overall magma output rate of Ciomadul, considering its $\sim 8.00 \pm 0.55 \mathrm{~km}^{3}$ original volume and the $\sim 850-<30 \mathrm{ka}$ time period of dome formation, is $9.70 \pm 0.51 \mathrm{~km}^{3} / \mathrm{My}$ (or $0.0097 \pm 0.00051 \mathrm{~km}^{3} / \mathrm{ky}$ ). Note that the errors are simply propagated from the overall error estimate presented in Table 1. This value is almost identical to the $\sim 9 \mathrm{~km}^{3} / \mathrm{My}$ suggested by Szakács et al. (2015) who, on this basis, inferred a low-frequency, low-output activity for the system.

However, such a rate can be refined, benefitting from the detailed volumetry of individual domes and the new $\mathrm{K}-\mathrm{Ar}$ ages. We divide the activity of Ciomadul-Puturosu into two stages (Fig. 4) Stage 1 involved formation of the older Puturosu, Balvanyos and Dealul Mare domes. These were emplaced between 850 and $440 \mathrm{ka}$ and are volumetrically much smaller than the domes of stage 2. Stage 2 involved formation of the younger, main lava dome complex over the past $\sim 200 \mathrm{ky}$, and encompasses $\sim 95 \%$ of the volume. According to the available radiometric ages, the two stages were separated by a $\sim 250$ ky repose period.

Based on Fig. 4 (see also Lahitte et al. this volume), the two stages of subsequent activity suggest two different magma output trends, with a moderate output rate followed by a significantly increased output rate. For the first stage (between $850-440 \mathrm{ka})$, the rate is $0.0012 \pm 0.0001 \mathrm{~km}^{3} / \mathrm{ky}$, whereas, after the quiescence, in the second stage $(\sim 200-30 \mathrm{ka})$ the rate is $0.0374 \pm 0.0019 \mathrm{~km}^{3} / \mathrm{ky}$. The $\sim 30$-fold increase means that most of Ciomadul's volume, $7.53 \pm 0.51 \mathrm{~km}^{3}$ (including the volcaniclastic aprons and the calculated erosion for the central dome area), was emplaced within the $\sim 200-30 \mathrm{ka}$ interval. Thus, magma output rate calculation depends on which time interval is considered: the increased rate during $\sim 200-<$ $30 \mathrm{ka}$ is a rate four times higher than the lifetime-averaged long-term output.

This finding modifies the conclusion of a generally low output over the lifetime of such a system. For example, White et al. (2006) reported long-term eruption rates for silicic volcanoes ranging from $<10^{-5} \mathrm{~km}^{3} / \mathrm{ky}$ to $10^{-2} \mathrm{~km}^{3} / \mathrm{yr}$., the average being $2.3 \pm 0.8 \times 10^{-3} \mathrm{~km}^{3} / \mathrm{yr}$. for andesites and 4.0 $\pm 1.4 \times 10^{-3} \mathrm{~km}^{3} / \mathrm{yr}$. for rhyolites. In this context, the $0.0012 \mathrm{~km}^{3} / \mathrm{ky}\left(=1.2 \times 10^{-3} \mathrm{~km}^{3} / \mathrm{ky}\right)$ magma output rate for stage 1 is low. However, the $3.74 \times 10^{-2} \mathrm{~km}^{3} / \mathrm{ky}$ magma output rate stage 2 , during which most lava domes were formed, is $10-15$ times higher than the worldwide average; even the long-term Ciomadul rate, averaged for the whole life time $\left(9.7 \times 10^{-3} \mathrm{~km}^{3} / \mathrm{ky}\right)$, is $2-4$ times higher than the worldwide average. As such, the second stage can be considered an exceptionally intense period of activity relative to the general decrease of magma output along the East Carpathians (e.g. Szakács et al. 1993; Karátson and Timár 2005; Szakács et al. 2015).

Eruption-scale magma output rates, commonly referred to as lava extrusion rates (i.e. those characterising the real emplacement of individual lava domes; cf. Fink and Anderson 2000), are another issue, which cannot be addressed using the available chronological data of Ciomadul, but require comparison with worldwide analogues. As seen from the aforementioned historical cases, domes with volumes of 0.1 to $0.5 \mathrm{~km}^{3}$ may be emplaced in several months up to tens
Fig. 4 Magma output rates of Ciomadul with time. Note the two different trends in the first and second stage with correlation coefficient values (coloured boxes). The range of values under the cumulative volume curve (marked as a grey area) shows the uncertainties of the given volume through time. The thin Gaussianlike individual curves refer to the left axis, whereas the thick black curve and the red and blue dashed trends refer to right axis

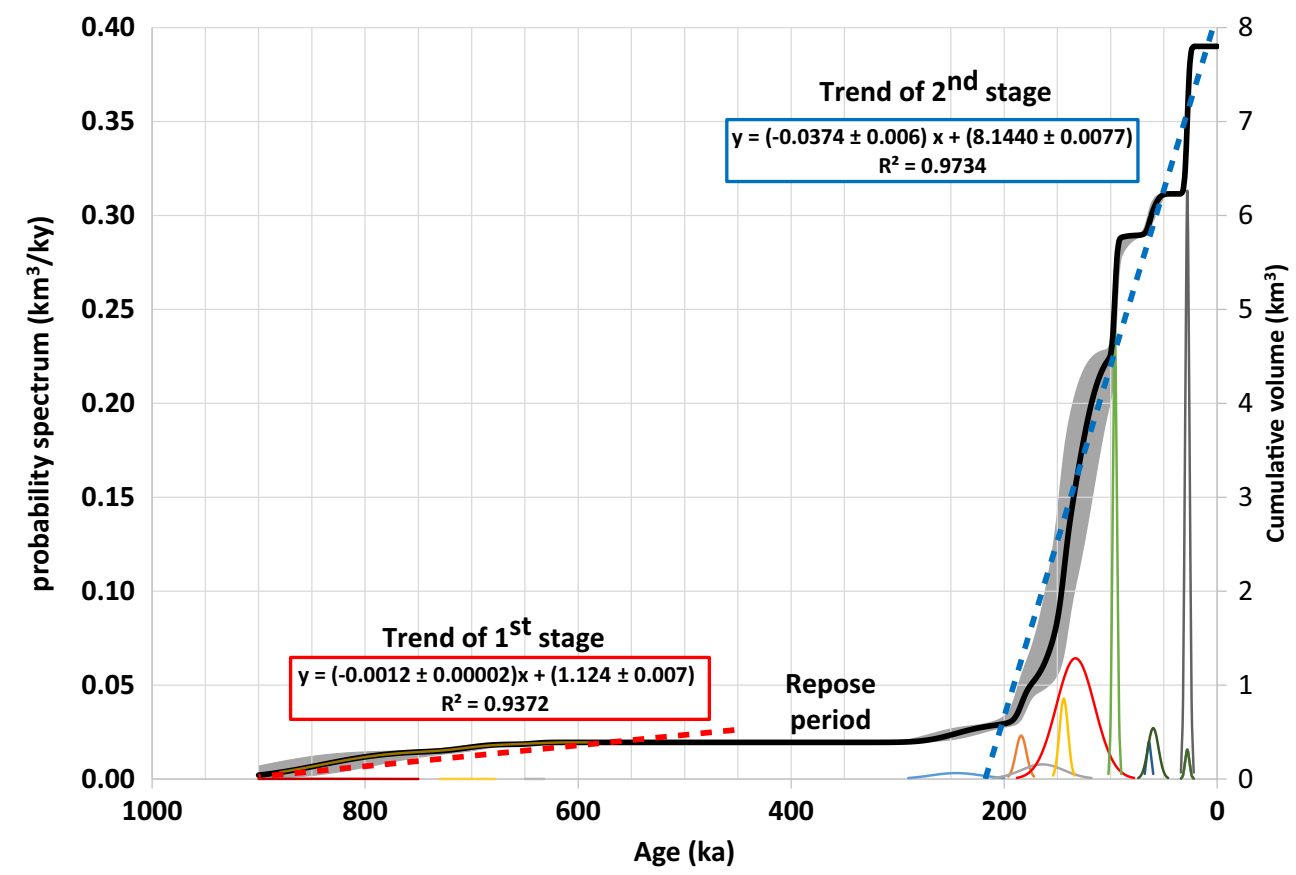


of years. The DomeHaz database (Ogburn et al. 2015) contains information for roughly 400 lava dome-forming episodes, less than half of which have reported durations (Wolpert et al. 2015). Most of the recorded dome-forming eruptions lasted $<6$ years. However, nine lasted $>20$ years, and five lasted $>50$ years (Wolpert et al. 2015). The longest durations include those of Santiaguíto, Guatemala (97 years since 1922, ongoing, Sangay, Ecuador (187 years, 17291916), and Merapi (251 years since 1768, ongoing). Notably, dome extrusion at Santiaguíto has been almost continuous (although variable between 0.2 and $2.1 \mathrm{~m}^{3} / \mathrm{s}$ (Rose 1987; Harris et al. 2003), but other long-lived eruptions showed frequent pauses up to several years.

The reported durations make it possible to obtain a frequency relationship. The near-linearity trend suggests that the durations follow a Pareto distribution (a power-law probability distribution: Wolpert et al. 2015). This finding, with respect to the duration of the longest-lived known eruptions (close to 300 years), implies that dome eruptions lasting for thousands of years (or even longer) are unlikely.

The case of Merapi volcano (Indonesia) gives insight into the temporal variation of lava extrusion over hundreds of years (e.g. Siswowidjoyo et al. 1995; Costa et al. 2013; Ogburn et al. 2015). The recent Merapi cone has a several thousand year-long eruptive history (Gertisser et al. 2012) and, in particular, is characterised by a period of dome extrusion since at least 1768 , when historical accounts of eruptions became more frequent (Voight et al. 2000). Records and assumptions suggest that all dome-forming episodes within this period were part of a continuous activity, fed by a constant magma supply, with intermittent explosions up to VEI $=4$ (Siswowidjoyo et al. 1995; Gertisser et al. 2011). Merapi's latest dome-forming eruptions in 2006 and 2010 showed observed lava extrusion rates of 2.5 to as high as $35 \mathrm{~m}^{3} / \mathrm{s}$ (Ratdomopurbo et al. 2013; Pallister et al. 2013). Such high rates can occur occasionally at a number of other lava domes worldwide, including Redoubt, 2009 (>30 m³ $/ \mathrm{s}$ maximum rate), Mt. St. Helens cryptodome, $1980\left(>40 \mathrm{~m}^{3} / \mathrm{s}\right.$ maximum rate), Shikotsu, 1909 (> $115 \mathrm{~m}^{3} / \mathrm{s}$ time average rate), or Rinjani, $1944\left(>120 \mathrm{~m}^{3} / \mathrm{s}\right.$ time average rate (Newhall and Melson 1983; Swanson and Holcomb 1990; Miller 1994; Fink and Griffiths 1998; Ogburn et al. 2015).

Numerically, such high rates during eruptive episodes are clearly smoothed out to long-term averages rates, such as those calculated here for Ciomadul. For instance, a $40 \mathrm{~m}^{3} / \mathrm{s}$ lava extrusion rate scales up to $1260 \mathrm{~km}^{3} / \mathrm{ky}$. This latter figure is 34,000 times higher than the secondstage magma output rate of $0.0374 \mathrm{~km}^{3} / \mathrm{ky}$ at Ciomadul, and implies long repose periods between the active episodes. The length of the inactive periods would thus have had time scales of tens or hundreds of thousands of years. For Ciomadul, Szakács et al. (2015) preferred a small number of eruptive stages separated by long repose intervals (on the order of $10^{5}$ years). To quantify the frequency distribution of eruptions within such eruptive stages, again we can take the example of Merapi volcano. Within its ongoing active period, for the time interval 1890-1992, a 100 -year average rate of $100,000 \mathrm{~m}^{3} /$ month (equalling to $1.2 \mathrm{~km}^{3} / \mathrm{ky}$ ) has been calculated (Siswowidjoyo et al. 1995). This rate is still 32 times higher than that during the second-stage activity at Ciomadul. Therefore, assuming, for instance, a Merapi-type intensity at Ciomadul, during its second stage the average repose period may have lasted $\sim 31$ times longer than an eruptive period (this period including dome-forming episodes and pauses, as observed at Merapi between 1890 and 1992).

\section{Implications for the volcano-geomorphological evolution of Ciomadul}

The geomorphological evolution of the lava dome complex is summarised in Fig. 5. The volcanism of the CiomadulPuturosu group developed on a gently westward-dipping erosional surface consisting mostly of Cretaceous flysch and rarer old ( $\sim 2 \mathrm{Ma})$ Pilişca andesites. The volcanism possibly occupied episodically the South Ciuc basin palaeolake (Fielitz and Seghedi 2005; Karátson et al. 2013). Following the emplacement of the older, isolated southern domes of Murgul Mare ( $2 \mathrm{Ma})$, Murgul Mic (age unknown) and the lava flows of Luget-Malnaş (also $\sim 2 \mathrm{Ma}$ ), the oldest Ciomadul domes (Dealul Mare, Puturosu and Balvanyos) were emplaced at $\sim 850-440 \mathrm{ka}$ (Fig. 5a). Dome volumes remained under $1 \mathrm{~km}^{3}$ in total. After a repose of ca. $250 \mathrm{ky}$, dome activity resumed in the north of the volcanic edifice (Haramul Mic $200 \mathrm{ka}$ ), followed by the Cetăţii dome at $\sim 180 \mathrm{ka}$, the Comloş and Ciomadul Mare central dome complex at $\sim 150$ $130 \mathrm{ka}$ (Fig. 5b), and eventually by the peripheral Haramul Mare dome at $\sim 100$ ka (Fig. 5c).

Karátson et al. (2013) proposed an explosion-craterforming event (with a crater diameter of $2-2.5 \mathrm{~km}$ ) that truncated the Ciomadul Mare dome(s). Based on the new $\mathrm{K}$-Ar age of $133 \pm 18 \mathrm{ka}$ for the Ciomadul Mare dome (Lahitte et al. this volume), such a large eruption could have occurred shortly after this date. On the other hand, timing of the Mohoș crater formation can now be wellconstrained by the newly obtained ages of the rim domes given here and Lahitte et al. (this volume). The Piscul Pietros lava dome (or flow) has a similar age as the Vf. Mohoș dome (60-65 ka, Table 2). Both domes were emplaced morphologically at or around the Mohoș crater rim. Piscul Pietros is cut by the crater rim, implying that the formation of Mohoș crater postdates the dome emplacement at around 65-60 ka. Following the explosive activity of the Mohos crater, the crater underwent 


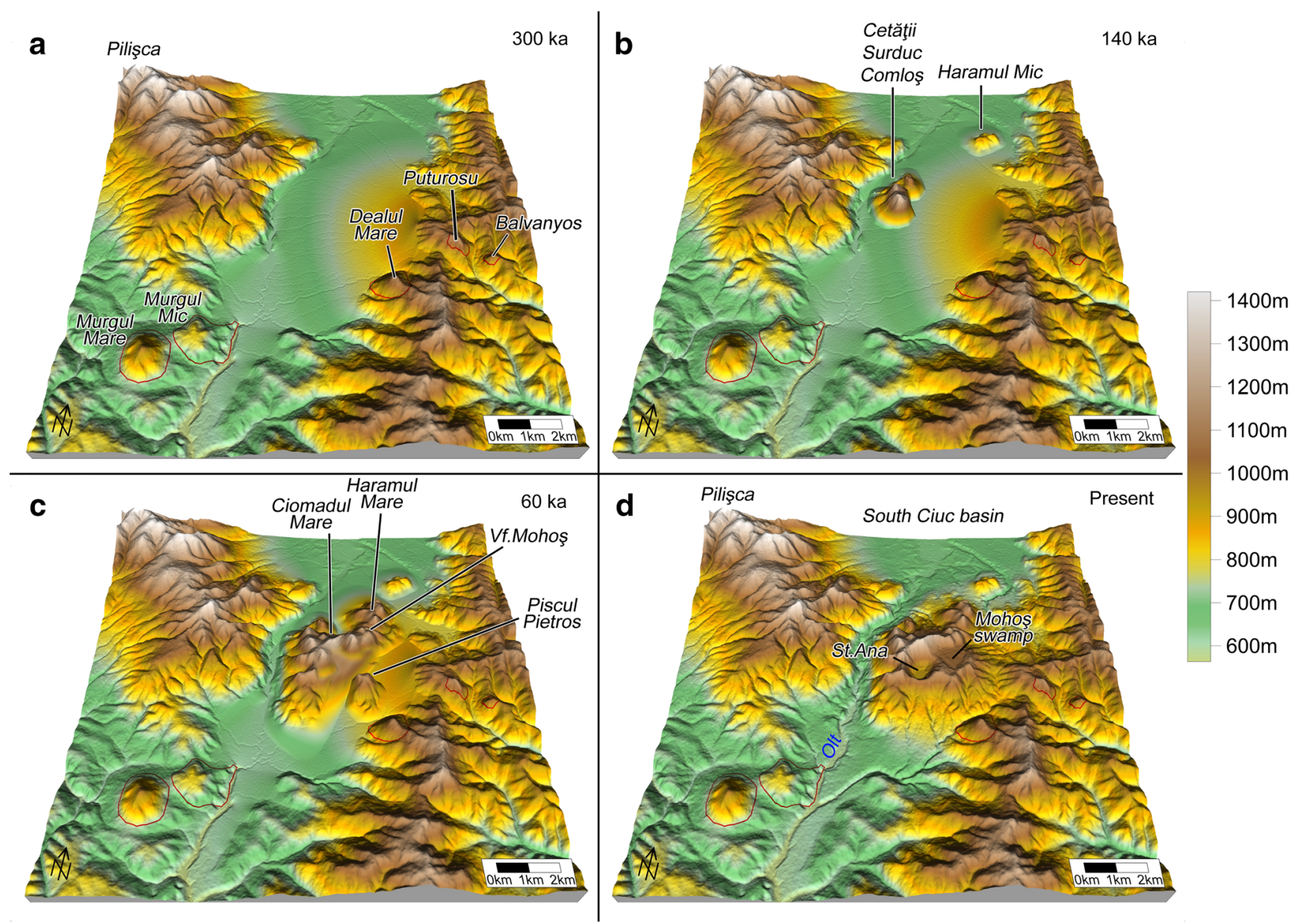

Fig. 5 Palaeo-geomorphological evolutionary stages of Ciomadul. a At $\sim 300 \mathrm{ka}$ : only the southeastern peripheral domes exist, which formed between $\sim 850-440 \mathrm{ka}$. b At $\sim 140 \mathrm{ka}$ : subsequent to the emplacement of Haramul Mic ( $200 \mathrm{ka}$ ), formation of the western domes takes place. $\mathbf{c}$ At $\sim 60$ ka: subsequent to the empacement of the central dome complex

(Ciomadul Mare, $\sim 130 \mathrm{ka}$ ), formation of the small domes of Vf. Mohos and Piscul Pietros takes place at $\sim 65-60 \mathrm{ka}$, no central craters exist. d Final explosive phase $(\sim 51-28 \mathrm{ka})$ which results in the current twincrater morphology of Mohos and St. Ana

progressive lacustrine infilling. The lacustrine succession comprises several tephra layers, e.g. the TGS and LSPA tephras presented above (Karátson et al. 2016; Wulf et al. 2016), that are interpreted to have originated from St. Ana crater, a new vent formed subsequent to the Mohoș crater (Fig. 5d).

This latest eruptive phase of Ciomadul has also been constrained in our study (Table 2) by dating the lava dome breccia that drape the southern crater slopes of St. Ana. The presence of this rock testifies that the final activity was not only explosive, as testified by the LSPA tephra, but also lava dome forming. This is suggested by the new $\mathrm{K}$-Ar age of $27.7 \pm 1.4 \mathrm{ka}$ which is in agreement with the oldest ${ }^{14} \mathrm{C}$ age of $27,180 \pm 462 \mathrm{cal}$ yr. BP of the St. Ana lacustrine sequence, i.e. the minimum formation age of the crater lake (Karátson et al. 2016), obtained from the deepest cored level (reaching into the pyroclastics deposits wrapping the crater bottom; Magyari et al. 2014). Moreover, within $2 \sigma$ error, the age is coeval with

the youngest ${ }^{14} \mathrm{C}$ age of $29,597 \pm 610$ cal yr. BP for the uppermost (LSPA) tephra layer in the Mohos crater (Karátson et al. 2016; Wulf et al. 2016). On this basis, we propose the final eruption (LSPA) to be responsible for excavating the present shape of St. Ana crater, which was presumably the site of the exploded, latest lava dome.

Notably, the last two explosive eruptions, i.e. TGS and LSPA, are stratigraphically and geochemically distinguishable in the Mohos lacustrine succession (Karátson et al. 2016; Wulf et al. 2016). To highlight that they are chronologically distinct, a simple graphic display presenting their $2 \sigma$ uncertainty is shown in Fig. 6. For the TGS eruption, we used the welldefined phase-2 pumiceous pyroclastic flow (Karátson et al. 2016), and all published ${ }^{14} \mathrm{C}$ and (U-Th)/He ages (Vinkler et al. 2007; Harangi et al. 2010, 2015; Karátson et al. 2016), while for the last eruption, our individual ages obtained on lava breccia are presented with error bars. The two ages do not overlap even at $2 \sigma$ level, and show that the last eruption took place at $<30 \mathrm{ka}$. 
Fig. 6 Distinction between the latest eruption of Ciomadul (new $\mathrm{K}$-Ar age $27.7 \pm 1.4 \mathrm{ka}, 1 \sigma$ ) (black solid line) with the age of the TGS eruption, phase 2 pyroclastic flow (pale grey solid line). Individual ages (solid vertical lines) are presented here at $2 \sigma$ uncertainty level. For the TGS eruption, age data are taken from the given references 1), 2) and 3). Dashed, striped diagonal patterns show the mean $2 \sigma$ uncertainties: $31.6 \pm 0.4 \mathrm{ka}$ for the TGS eruption, and $27.7 \pm 2.8 \mathrm{ka}$ for the latest eruption

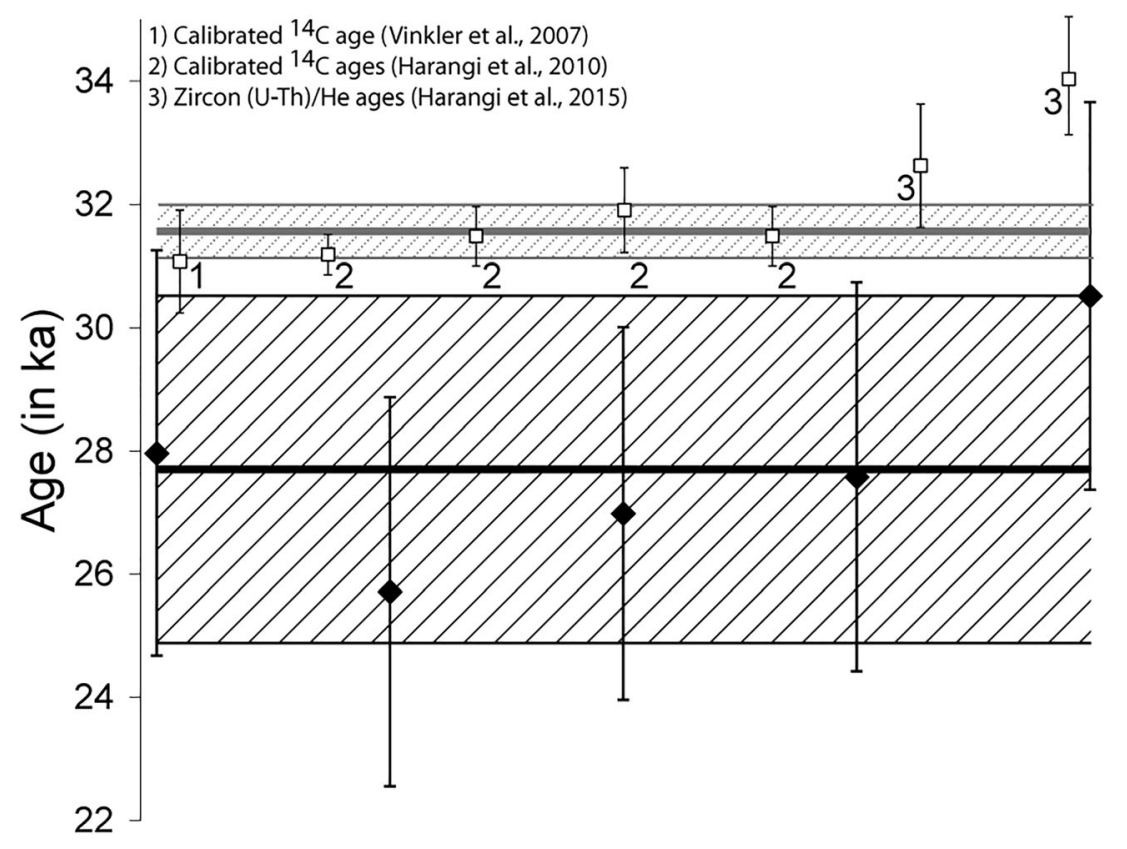

\section{Conclusions}

Careful volumetrical analysis, taking into account the presentday volumes of the lava domes constituting the Ciomadul lava dome complex, their base level and the erosionally removed material, suggests a total volume of $\sim 8 \mathrm{~km}^{3}$. By using new KAr ages obtained by the Cassignol-Gillot technique, we have determined long-term magma output rates during emplacement of this volume $(\sim 850$ to $<30 \mathrm{ka})$. Our main finding is that magma output varied significantly during the lifetime of the volcanic complex, with output rates being more than 30 times higher during the second eruptive stage $(\sim 200$ to $<$ $30 \mathrm{ka})$ than during the first stage $(\sim 850$ to $440 \mathrm{ka})$. Moreover, our results help clarify the main steps of the volcano-geomorphological evolution of Ciomadul, in particular at the central crater area.

In detail, Ciomadul represents a medium-sized lava dome complex. Its total volume of $\sim 8.00 \pm 0.55 \mathrm{~km}^{3}$ (including erosionally removed material which is only $\sim 2 \%$ ) spreads over an area of $74.5 \mathrm{~km}^{2}$. The first extrusive volcanic stage between $\sim 850$ to $450 \mathrm{ka}$, constrained to the SE part, was volumetrically subordinate, whereas, after a $\sim 250$ ky repose period, the central dome complex was emplaced in the second stage between $\sim 200$ to $<30$ ka representing most of the total volume of the volcanic edifice $\left(\sim 7.53 \pm 0.51 \mathrm{~km}^{3}\right)$. For the whole lifetime of Ciomadul, a long-term magma output rate of $9.7 \mathrm{~km}^{3} / \mathrm{My}$ $\left(0.0097 \mathrm{~km}^{3} / \mathrm{ky}\right)$ can be calculated. Within this, the first stage was characterised by a low magma output rate of $0.0011 \mathrm{~km}^{3} /$ My, whereas the second stage by a significantly increased magma output rate of $0.0374 \mathrm{~km}^{3} / \mathrm{My}$. The smallest distinguishable domes at Ciomadul are characterised by volumes in the range of $0.1-0.4 \mathrm{~km}^{3}$, similar to, for example those at
Soufrière Hills (Montserrat). These domes could have erupted over several years or decades. Although the chronological resolution of individual eruptions (and related volumes) cannot be assessed, it can be quantified, based on worldwide analogues, that active periods of Ciomadul's lava dome extrusion, which lasted up to hundreds of years, may have been separated by repose periods lasting $\sim 30$ times longer.

Our findings also constrain the geomorphic evolution of the dome complex which yields an example of milleniascale evolution of medium-sized extrusive silicic systems. Based on the main findings at Ciomadul, lava dome activity can last for hundreds of ky producing small volumes $(\leq$ $1 \mathrm{~km}^{3}$ ). Individual domes of $0.1-1.0 \mathrm{~km}^{3}$ in volume can grow separately, however, they can also coalesce to form compound landforms on a $1.0 \mathrm{~km}^{3}$ scale. As the Ciomadul example suggests, reaching a volume up to $10 \mathrm{~km}^{3}$ can occur at a timescale of $100 \mathrm{ky}$. The domes may display central craters, which can be filled, covered and/or obliterated by subsequent lava dome eruptions. At Ciomadul, the formation of relatively large craters $(\leq 2 \mathrm{~km}$ in diameter) was due to an increased late-stage explosivity (and no dome infill at the end), although the volume of pyroclastic products that makes up the dome complex is less than one-tenth of the extruded lava rocks.

Acknowledgements Constructive reviews by Károly Németh and Mike James and editorial handling by Stephen Self and Andrew Harris are appreciated.

Funding information Open access funding provided by Eötvös Loránd University (ELTE). This work has been supported by the Hungarian Scientific Research Fund NKFIH-OTKA No. K 115472 to DK. Financial support for PL and SD was also provided by the SYSTER 2017 program of INSU, CNRS. 


\section{Appendix}

Error factors in volume calculations for selected volcanic edifices (modified and completed on the basis of Telbisz et al. 2017)

Table 4 Error factors in volume calculations for selected volcanic edifices (modified and completed on the basis of Telbisz et al. 2017)

\begin{tabular}{|c|c|c|c|c|c|c|c|c|c|c|c|c|}
\hline \multirow[t]{3}{*}{ Name } & \multirow{3}{*}{$\begin{array}{l}\mathrm{V}_{\mathrm{ref}} \\
\left(\mathrm{km}^{3}\right)\end{array}$} & \multirow{3}{*}{$\begin{array}{l}\text { Area } \\
\left(\mathrm{km}^{2}\right)\end{array}$} & \multirow{3}{*}{$\begin{array}{l}\text { Height } \\
(\mathrm{m})\end{array}$} & \multirow{3}{*}{$\begin{array}{l}\text { best } \\
\text { resolution }\end{array}$} & \multicolumn{8}{|c|}{ Volume differences $(\mathrm{dV}, \%)$ relative to $\mathrm{V}_{\text {ref }}$ due to } \\
\hline & & & & & \multicolumn{2}{|c|}{ resolution diff. } & \multicolumn{2}{|c|}{$\begin{array}{l}\text { integration } \\
\text { method }\end{array}$} & \multicolumn{2}{|c|}{$\begin{array}{l}\text { delimitation diff. } \\
(1 \% \text { of } R)\end{array}$} & \multicolumn{2}{|c|}{$\begin{array}{l}\text { base level diff. (1\% } \\
\text { of height) }\end{array}$} \\
\hline & & & & & $\mathrm{dV}_{1 \mathrm{~s}}$ & $\mathrm{dV}_{3 \mathrm{~s}}$ & $\mathrm{dV}_{\text {rect }}$ & $\mathrm{dV}_{\text {Simp }}$ & $\begin{array}{l}\mathrm{dR} \\
(m)\end{array}$ & $\begin{array}{l}\mathrm{dV}_{\mathrm{del}} \\
(\%)\end{array}$ & $\begin{array}{l}\mathrm{dBL} \\
(m)\end{array}$ & $\begin{array}{l}\mathrm{dV}_{\mathrm{BL}} \\
(\%)\end{array}$ \\
\hline $\begin{array}{l}\text { Unnamed dome (Shasta } \\
\text { North; USA) }\end{array}$ & 0.07 & 0.8 & 464 & $1 / 9 "$ & $1.45 \%$ & $2.31 \%$ & $0.13 \%$ & $0.00 \%$ & 5 & $1.2 \%$ & 5 & $3.3 \%$ \\
\hline Puu Waawaa (USA) & 0.18 & 2.0 & 407 & $1 / 3 "$ & $4.61 \%$ & $2.24 \%$ & $0.05 \%$ & $0.01 \%$ & 8 & $0.9 \%$ & 4 & $5.0 \%$ \\
\hline Murgul Mare (ROM) & 0.27 & 3.0 & 326 & $1 "$ & & $0.44 \%$ & $0.16 \%$ & $0.02 \%$ & 10 & $0.4 \%$ & 3 & $3.1 \%$ \\
\hline $\begin{array}{l}\text { Black Butte (Shasta; } \\
\text { USA) }\end{array}$ & 1.12 & 5.5 & 764 & $1 / 3 "$ & $0.95 \%$ & $1.01 \%$ & $0.04 \%$ & $0.00 \%$ & 13 & $0.3 \%$ & 8 & $3.3 \%$ \\
\hline Putauaki (New Zealand) & 1.62 & 9.6 & 773 & $1 / 3 "$ & $7.12 \%$ & $6.64 \%$ & $0.00 \%$ & $0.00 \%$ & 17 & $0.4 \%$ & 8 & $4.7 \%$ \\
\hline Lookout (Or, USA) & 3.36 & 27.3 & 184 & $1 / 3^{\prime \prime}$ & $6.01 \%$ & $6.10 \%$ & $0.00 \%$ & $0.00 \%$ & 29 & $0.4 \%$ & 2 & $1.7 \%$ \\
\hline Ciomadul (ROM), whole & 7.80 & 72.9 & 721 & $1 "$ & & $0.02 \%$ & $0.14 \%$ & $0.00 \%$ & 48 & $1.6 \%$ & 7 & $5.4 \%$ \\
\hline Crater Mt. (Ca, USA) & 12.03 & 87.4 & 578 & $1 / 3 "$ & $5.23 \%$ & $5.19 \%$ & $0.00 \%$ & $0.00 \%$ & 53 & $0.2 \%$ & 6 & $4.4 \%$ \\
\hline Sutter Buttes (Ca, USA) & 16.43 & 182.5 & 634 & $1 / 3^{\prime \prime}$ & $0.44 \%$ & $0.45 \%$ & $0.00 \%$ & $0.00 \%$ & 76 & $0.1 \%$ & 6 & $7.8 \%$ \\
\hline Burney (USA) & 18.81 & 117.4 & 1472 & $1 / 3 "$ & $2.28 \%$ & $2.40 \%$ & $0.01 \%$ & $0.00 \%$ & 61 & $1.1 \%$ & 15 & $9.8 \%$ \\
\hline Tongariro (New Zealand) & 101.65 & 496.4 & 1816 & $1 / 3 "$ & $1.24 \%$ & $1.04 \%$ & $0.00 \%$ & $0.00 \%$ & 126 & $1.1 \%$ & 18 & $10.1 \%$ \\
\hline Ruapehu (New Zealand) & 244.13 & 1176.9 & 2383 & $1 / 3^{\prime \prime}$ & $1.83 \%$ & $1.91 \%$ & $0.00 \%$ & $0.00 \%$ & 194 & $1.0 \%$ & 24 & $12.5 \%$ \\
\hline Adams (USA) & 310.22 & 756.0 & 3182 & $1 / 3 "$ & $1.18 \%$ & $1.23 \%$ & $0.00 \%$ & $0.00 \%$ & 155 & $1.0 \%$ & 32 & $8.3 \%$ \\
\hline Shasta (USA), whole & 327.84 & 767.8 & 3510 & $1 / 3 "$ & $1.07 \%$ & $1.08 \%$ & $0.01 \%$ & $0.00 \%$ & 156 & $1.0 \%$ & 35 & $5.8 \%$ \\
\hline Minimum & 0.1 & 0.8 & 183.9 & & $0.44 \%$ & $0.02 \%$ & $0.00 \%$ & $0.00 \%$ & 5 & $0.09 \%$ & 2 & $1.7 \%$ \\
\hline Maximum & 327.8 & 1176.9 & 3510.3 & & $7.12 \%$ & $6.64 \%$ & $0.16 \%$ & $0.02 \%$ & 194 & $1.61 \%$ & 35 & $12.5 \%$ \\
\hline Mean & 74.7 & 264.7 & 1229.6 & & $2.78 \%$ & $2.29 \%$ & $0.04 \%$ & $0.00 \%$ & 68 & $0.76 \%$ & 12 & $6.1 \%$ \\
\hline
\end{tabular}

$V_{\text {ref }}$, reference volume calculated from the best resolution DTM, the most reliable delimitation and base level, using trapezoidal rule integration method; $d V_{1 s}, d V_{3 s}$, volume difference between $V_{\text {ref }}$ and the volume got by using 1" (3") SRTM; $d V_{\text {rect }}$, volume difference between $V_{\text {ref }}$ and the volume got by using rectangular rule; $d V_{\text {Simp }}$, volume difference between $V_{\text {ref }}$ and the volume got by using Simpson's rule method; $d V_{\text {del }}$, volume difference between $\mathrm{V}_{\text {ref }}$ and the volume got by changing the volcano outline by $1 \%$ of the mean radius (dR); $d V_{B L}$, volume difference between $\mathrm{V}_{\text {ref }}$ and the volume got by changing the volcano base level by $1 \%$ of height (dBL) 
Open Access This article is distributed under the terms of the Creative Commons Attribution 4.0 International License (http:// creativecommons.org/licenses/by/4.0/), which permits unrestricted use, distribution, and reproduction in any medium, provided you give appropriate credit to the original author(s) and the source, provide a link to the Creative Commons license, and indicate if changes were made.

\section{References}

Bányai J (1917) Kézdivásárhely vidéke Háromszék vármegyében (The land of Kézdivásárhely in Háromszék county; in Hungarian). Földtani Közlöny (Bull Hung Geol Soc) XLVII:1-20

Bányai J (1964) The eruptive age of Lake Szent Anna twin craters (a Szent Anna-tavi ikerkráter erupciójának kora; in Hungarian). Földrajzi Értesítő (Hung Geogr Bull) XIII(1):57-66

Bemis K, Ferencz M (2017) Morphometric analysis of scoria cones: the potential for inferring process from shape. In: Németh K, CarrascoNuñez G, Aranda-Gomez JJ, Smith IEM (eds) Monogenetic Volcanism. Geol Soc London spec Publ 446, 61-100

Bemis K, Walker J, Borgia A, Turrin B, Neri M, Swisher C (2011) The growth and erosion of cinder cones in Guatemala and El Salvador: models and statistics. J Volcanol Geotherm Res 201(1):39-52

Blake S (1989) Viscoplastic models of lava domes, IAVCEI Proceddings in Volcanology, Vol 2, Lava flows and domes. Springer Verlag, Heidelberg, pp 88-126

Bohnenstiehl DR, Howell JK, White SM, Hey RN (2012) A modified basal outlining algorithm for identifying topographic highs from gridded elevation data, part 1: motivation and methods. Comput Geosci 49:308-314

Boudon G, Balcone-Boissard H, Villemant B, Morgan DJ (2015) What factors control superficial lava dome explosivity? Sci Rep 5, Article number: 14551. https://doi.org/10.1038/srep14551

Bulla B (1948) A két Csiki-medence és az Olt-völgy kialakulásáról (on the formation of the two Ciuc basins and Olt valley; in Hungarian). Földrajzi Közlemények (Bull Hung Geogr Soc) LXXVI:134-156

Capra L, Roverato M, Groppelli G, Caballero L, Sulpizio R, Norini G (2015) Glacier melting during lava dome growth at Nevado de Toluca volcano (Mexico): evidences of a major threat before main eruptive phases at ice-caped volcanoes. J Volcanol Geotherm Res 294:1-10

Carr BB, Clarke AB, Vanderkluysen L (2016) The 2006 lava dome eruption of Merapi volcano (Indonesia): detailed analysis using MODIS TIR. J Volcanol Geotherm Res 311:60-71

Chalot-Prat F, Gîrbacea R (2000) Partial delamination of continental mantle lithosphere, uplift-related crust-mantle decoupling, volcanism and basin formation: a new model for the Pliocene-quaternary evolution of the southern East-Carpathians, Romania. Tectonophysics 327:83-107

Charbonnier SJ, Gertisser R (2008) Field observations and surface characteristics of pristine block-and-ash flow deposits from the 2006 eruption of Merapi volcano, Java, Indonesia. J Volcanol Geotherm Res 177:971-982

Christiansen RL, Lowenstern JB, Smith RB, Heasler H, Morgan LA, Nathenson M, Mastin LG, Muffler LJP, Robinson JE (2007) Preliminary assessment of volcanic and hydrothermal hazards in Yellowstone National Park and vicinity. US Geol Surv Open-File Report 2007-1071, 94 p

Costa F, Andreastuti S, Bouvet de Maisonneuve C, Pallister JS (2013) Petrological insights into the storage conditions, and magmatic processes that yielded the centennial 2010 Merapi explosive eruption. J Volcanol Geotherm Res 261:209-235
Davidson J, de Silva S (2000) Composite volcanoes. In: Sigurdsson H et al (eds) Encyclopedia of volcanoes. Academic, New York, pp 663-681

de Silva SL, Self S, Francis PW, Drake RE, Ramirez RR (1994) Effusive silicic volcanism in the Central Andes: the Chao dacite and other young lavas of the Altiplano-Puna volcanic complex. J Geophys Res 99:17,805-17,825

Diefenbach AK, Bull KF, Wessels RL, McGimsey RG (2013) Photogrammetric monitoring of lava dome growth during the 2009 eruption of redoubt volcano. J Volcanol Geotherm Res 259:308-316

Euillades LD, Grosse P, Euillades PA (2013) NETVOLC: an algorithm for automatic delimitation of volcano edifice boundaries using DEMs. Comput Geosci 56:151-160

Favalli M, Karátson D, Mazzarini F, Pareschi MT, Boschi E (2009) Morphometry of scoria cones located on a volcano flank: a case study from Mt. Etna (Italy), based on high-resolution LiDAR data. J Volcanol Geotherm Res 186(3-4):320-330

Favalli M, Fornaciai A, Mazzarini F, Harris A, Neri M, Behncke B, Pareschi MT (2010) Evolution of an active lava flow field using a multitemporal LIDAR acquisition. J Geophys Res 115:B11203

Fielitz W, Seghedi I (2005) Late Miocene-Quaternary volcanism, tectonics and drainage system evolution on the East Carpathians, Romania. In: Cloetingh $\mathrm{S}$ et al. (eds) Special volume fourth Stephan Müller conference of the EGU on geodynamic and tectonic evolution of the Carpathian arc and its foreland. Tectonophys 410: $111-136$

Fink JH, Anderson SW (2000) Lava domes and coulées. In: Sigurdsson H et al (eds) Encyclopedia of volcanoes. Academic, New York, pp 317-319

Fink JH, Anderson SW (2017) Emplacement of Holocene silicic lava flows and domes at Newberry, South Sister, and Medicine Lake volcanoes, California and Oregon. US Geol Surv Sci Investigations Rep 2017-5022-I, 41 p. https://doi.org/10.3133/ sir20175022I

Fink JH, Griffiths RW (1998) Morphology, eruption rates, and rheology of lava domes: Insights from laboratory models. J Geophys Res 103(527) https://doi.org/10.1029/97JB02838

Fornaciai A, Behncke B, Favalli M, Neri M, Tarquini S, Boschi E (2010) Detecting short-term evolution of Etnean scoria cones: a LIDARbased approach. Bull Volcanol 72:1209-1222

Fornaciai A, Favalli M, Karátson D, Tarquini S, Boschi E (2012) Morphometry of scoria cones, and their relation to geodynamic setting: A DEM-based analysis. J Volcanol Geotherm Res 217:56-72

Germa A, Quidelleur X, Labanieh S, Lahitte P, Chauvel C (2010) The eruptive history of Morne Jacob volcano (Martinique Island, French West Indies): Geochronology, geomorphology and geochemistry of the earliest volcanism in the recent Lesser Antilles arc

Germa A, Lahitte P, Quidelleur X (2015) Construction and destruction of Mont Pelée volcano: volumes and rates constrained from a geomorphological model of evolution. J Geophys Res Earth Surf 120(7): $1206-1226$

Gertisser R, Charbonnier SJ, Troll VR, Keller J, Preece K, Chadwick JP, Barclay J, Herd RA (2011) Merapi (Java, Indonesia): anatomy of a killer volcano. Geol Today 27(2):57-62

Gertisser R, Charbonnier SJ, Keller J, Quidelleur X (2012) The geological evolution of Merapi volcano, Central Java, Indonesia. Bull Volcanol 74:1213-1233

Gillot PY, Cornette Y (1986) The Cassignol technique for potassiumargon dating, precision and accuracy - examples from the late Pleistocene to recent volcanics from southern Italy. Chem Geol 59: 205-222

Grosse P, Kervyn M (2018) Morphometry of terrestrial shield volcanoes. Geomorphology 304:1-14

Grosse P, van Wyk de Vries B, Petrinovic IA, Euillades PA, Alvarado GE (2009) Morphometry and evolution of arc volcanoes. Geology 37(7):651-654 
Grosse P, van Wyk de Vries B, Euillades PA, Kervyn M, Petrinovic IA (2012) Systematic morphometric characterization of volcanic edifices using digital elevation models. Geomorphology 136(1):114 131

Hale AJ, Wadge G (2008) The transition from endogenous to exogenous growth of lava domes with the development of shear bands. J Volcanol Geotherm Res 171(3-4):237-257

Harangi S, Molnár M, Vinkler AP, Kiss B, Tull AJT, Leonard AG (2010) Radiocarbon dating of the last volcanic eruptions of Ciomadul volcano, Southeast Carpathians, eastern-central Europe. Radiocarbon 52(2-3):1498-1507

Harangi S, Lukács R, Schmitt AK, Dunkl I, Molnár K, Kiss B, Seghedi I, Novothny Á, Molnár B (2015) Constraints on the timing of quaternary volcanism and duration of magma residence at Ciomadul volcano, east-central Europe, from combined U-Th/He and U-Th zircon geochronology. J Volcanol Geotherm Res 301:66-80

Harris AJL, Rose WI, Flynn LP (2003) Temporal trends in lava dome extrusion at Santiaguito 1922-2000. Bull Volcanol 65(2-3):77-89

Harris AJL, Vallance JW, Kimberly P, Rose WI, Matías O, Bunzendahl E, Flynn LP, Garbeil H (2006) Downstream aggradation owing to lava dome extrusion and rainfall runoff at Volcán Santiaguito, Guatemala. In: Rose WI, Bluth GJS, Carr MJ, Ewert JW, Patino LC, Vallance JW (eds) Volcanic hazards in Central America. Geol Soc Amer spec paper 412: 85-104

Hildreth W (1983) The compositionally zoned eruption of 1912 in the Valley of Ten Thousand Smokes, Katmai National Park, Alaska. J Volcanol Geotherm Res 18(1-4):1-56

Hildreth W, Fierstein J (2012) The Novarupta-Katmai eruption of 1912 largest eruption of the twentieth century; centennial perspectives. US Geol Surv Prof Pap 1791:259

Jánosi Cs (1983) Prospecțiuni pentru piatră ponce in perimetrul TușnadBixad (Județele Harghita, Covasna), Scale 1:5000. Unpublished geological report, I.P.E.G., Miercurea Ciuc, Romania

Karátson D (1996) Rates and factors of stratovolcano degradation in a continental climate: a complex morphometric analysis of nineteen Neogene/Quaternary crater remnants in the Carpathians. J Volcanol Geotherm Res 73:65-78

Karátson D (2007) From Börzsöny to Hargita. Volcanology, geomorphic evolution, paleogeography (in Hungarian). Typotex, Budapest, pp. 463

Karátson D, Timár G (2005) Comparative volumetric calculations of two segments of the Carpathian Neogene/Quaternary volcanic chain using SRTM elevation data: implications for erosion and magma output rates. Z Geomorphol Suppl 140:19-35

Karátson D, Telbisz T, Singer BB (2010a) Late-stage volcano-geomorphic evolution of the Pleistocene San Francisco Mountain, Arizona (USA), on the basis of high-resolution DEM analysis and Ar-Ar chronology. Bull Volcanol 72:833-846

Karátson D, Favalli M, Tarquini S, Fornaciai A, Wörner G (2010b) The regular shape of stratovolcanoes: a DEM-based morphometrical approach. J Volcanol Geotherm Res 193:171-181

Karátson D, Telbisz T, Wörner G (2012) Erosion rates and erosion patterns of Neogene to Quaternary stratovolcanoes in the Western Cordillera of the Central Andes: an SRTM DEM based analysis. Geomorphology 139-140:122-135

Karátson D, Telbisz T, Harangi SZ, Magyari E, Dunkl I, Kiss B, Jánosi CS, Veres D, Braun M, Fodor E, Biró T, Kósik SZ, von Eynatten H, Lin D (2013) Morphometrical and geochronological constraints on the youngest eruptive activity in East-Central Europe at the Ciomadul (Csomád) lava dome complex, East Carpathians. J Volcanol Geotherm Res 157-158:56-72

Karátson D, Wulf S, Veres D, Magyari EK, Gertisser R, Timar-Gabor A, Novothny Á, Telbisz T, Szalai Z, Appelt O, Bormann M, Jánosi CS, Hubay K, Schäbitz F (2016) The latest explosive eruptions of Ciomadul (Csomád) volcano, East Carpathians - a tephrostratigraphic approach for the 51-29 ka BP time interval. J Volcanol Geotherm Res 319:29-51

Karátson D, Veres D, Wulf S, Gertisser R, Magyari EK, Bormann M (2017) The youngest volcanic eruptions in East-Central Europenew findings from the Ciomadul lava dome complex, East Carpathians, Romania. Geol Today 33(2):60-65

Karátson D, Veres D, Lahitte P, Wulf S, Telbisz S, Szakács A, Gertisser R, Novothny Á, Dibacto S (2018a) Volcanic and geomorphic evolution of the Late Quaternary Ciomadul lava dome complex, the youngest eruptive center of the Carpathian Basin. In: Hambach U, Veres D (eds) Crossing New Frontiers: INTAV International Field Conference on Tephrochronology, "Tephra Hunt in Transylvania", Moieciu de Sus, Romania. Book of Abstracts, Keynote 5, 23-24 pp

Karátson D, Telbisz T, Lahitte P, Dibacto S, Veres D, Szakács A, Gertisser R, Jánosi Cs (2018b) Magma output rates of the Late Quaternary Ciomadul (Csomád) lava dome complex using digital elevation model (DEM) volumetry and Cassignol - Gillot K-Ar dating. In: Mattoni S (ed) Cities on Volcanoes 10: "Millenia of Stratification between Human Life and Volcanoes: strategies for coexistence", Naples, Italy. Abstracts Volume, Istituto Nazionale di Geofisica e Vulcanologia, p 355

Kereszturi G, Németh K (2012) Structural and morphometric irregularities of eroded Pliocene scoria cones at the Bakony-Balaton Highland volcanic field, Hungary. Geomorphology 136:45-58

Kereszturi G, Procter J (2016) Error in topographic attributes for volcanic hazard assessment of the Auckland Volcanic Field (New Zealand). New Zealand J Geol Geophys 59(2):286-301

Kereszturi G, Németh K, Cronin SJ, Agustin-Flores J, Smith IEM, Lindsay J (2013) A model for calculating eruptive volumes for monogenetic volcanoes - implication for the Quaternary Auckland Volcanic Field, New Zealand. J Volcanol Geotherm Res 266:16-33

Kervyn M, Ernst GGJ, Goossens R, Jacobs P (2008) Mapping volcano topography with remote sensing: ASTER vs. SRTM. Int J Remote Sens 29(22):6515-6538

Kervyn M, Ernst GGJ, Carracedo JC, Jacobs P (2012) Geomorphometric variability of "monogenetic" volcanic cones: evidence from Mauna Kea, Lanzarote and experimental cones. Geomorphology 136:5975

Kis BM, Ionescu A, Cardellini C, Harangi S, Baciu C, Caracausi A, Viveiros F (2017) Quantification of carbon dioxide emissions of Ciomadul, the youngest volcano of the Carpathian-Pannonian Region (Eastern-Central Europe, Romania). J Volcanol Geotherm Res 341:119-130

Kiss B, Harangi S, Ntaflos T, Mason PRD, Pál-Molnár E (2014) Amphibole perspective to unravel pre-eruptive processes and conditions in volcanic plumbing systems beneath intermediate arc volcanoes: a case study from Ciomadul volcano (SE Carpathians). Contrib Mineral Petrol 167(3):1-27

Kuenzi WD, Horst OH, McGehee RV (1979) Effect of volcanic activity on fluvial-deltaic sedimentation in a modern arc-trench gap, southwestern Guatemala. Geol Soc Am Bull 90:827-838

Lahitte P, Samper A, Quidelleur X (2012) DEM-based reconstruction of southern Basse-Terre volcanoes (Guadeloupe archipelago, FWI): contribution to the Lesser Antilles Arc construction rates and magma production. Geomorphology 136(1):148-164

Lahitte P, Dibacto S, Karátson D, Gertisser R, Veres D (this volume) Eruptive history of the Late Quaternary Ciomadul (Csomád) volcano, East Carpathians I: timing of lava dome activity constrained by the unspiked K-Ar method. Bull Volcanol xxx

Lavigne F, Degeai J-P, Komorowski J-C, Guillet S, Robert V, Lahitte P, Oppenheimer C, Stoffel M, Vidal CM, Surono, Pratomo I, Wassmer P, Hajdas I, Hadmoko DS, de Belizal E (2013) Source of the great A.D. 1257 mystery eruption unveiled, Samalas volcano, Rinjani Volcanic Complex, Indonesia. Proc Natl Acad Sci U S A 110(42): 16742-16747 
Lexa J, Seghedi I, Németh K, Szakács A, Konečný V, Pécskay Z, Fülöp A, Kovács M (2010) Neogene-Quaternary volcanic forms in the Carpathian-Pannonian Region: a review. Central Eur J Geosci 2(3):207-210

Lockwood JP, Hazlett RW (2010) Volcanoes-global perspectives. WileyBlackwell $552 \mathrm{p}$

Magyari EK, Veres D, Wennrich V, Wagner B, Braun M, Jakab G, Karátson D, Pál Z, Ferenczy GY, St-Onge G, Rethemeyer J, Francois JP, von Reumont F, Schäbitz F (2014) Vegetation and environmental responses to climate forcing during the Last Glacial Maximum and deglaciation in the East Carpathians: attenuated response tomaximum cooling and increased biomass burning. Quat Sci Rev 106:278-298

Mason PRD, Seghedi I, Szakács A, Downes H (1998) Magmatic constraints on geodynamic models of subduction in the Eastern Carpathians, Romania. Tectonophys 297:157-176

Miller TP (1994) Dome growth and destruction during the 1989-1990 eruption of Redoubt volcano. J Volcanol Geotherm Res 62(1-4): $197-212$

Molnár K, Harangi SZ, Lukács R, Dunkl I, Seghedi I, Schmitt AK, Kiss B, Garamhegyi T, Seghedi I (2018) The onset of the volcanism in the Ciomadul Volcanic Dome Complex (Eastern Carpathians): eruption chronology and magma type variation. J Volcanol Geotherm Res 354:39-56

Moriya I, Okuno M, Nakamura T, Szakács A, Seghedi I (1995) Last eruption and its $14 \mathrm{C}$ age of Ciomadul volcano, Romania (in Japanese with English abstract). Summaries of Researches Using AMS at Nagoya University, VI, 82-91

Moriya I, Okuno M, Nakamura T, Ono K, Szakács A, Seghedi I (1996) Radicarbon ages of charcoal fragments from the pumice flow deposit of the last eruption of Ciomadul volcano, Romania (in Japanese with English abstract). Summaries of Researches Using AMS at Nagoya University, VII, 252-255

Nakada S, Shimizu H, Ohta K (1999) Overview of the 1990-1995 eruption at Unzen volcano. J Volcanol Geotherm Res 89(1-4):1-22

Newhall CG, Melson WG (1983) Explosive activity associated with the growth of volcanic domes. J Volcanol Geophys Res 17:111-131

Nomikou P, Parks MM, Papanikolaou D, Pyle DM, Mather TA, Carey S, Watts AB, Paulatto M, Kalnins ML, Livanos I, Bejelou K, Simou E, Perros I (2014) The emergence and growth of a submarine volcano: the Kameni islands, Santorini (Greece). GeoRes J 1:8-18

Ogburn SE, Loughlin SC, Calder ES (2015) The association of lava dome growth with major explosive activity (VEI $\geq 4)$ : DomeHaz, a global dataset. Bull Volcanol 77:40. https://doi.org/10.1007/s00445-0150919-x

Pallister JS, Schneider DJ, Griswold JP, Keeler RH, Burton WC, Noyles C, Newhall CG, Ratdomopurbo A (2013) Merapi 2010 eruptionChronology and extrusion rates monitored with satellite radar and used in eruption forecasting. J Volcanol Geotherm Res 261:144-152

Pécskay Z, Edelstein O, Seghedi I, Szakács A, Kovacs M, Crihan M, Bernad A (1995) K-Ar datings of the Neogene-Quaternary calcalkaline volcanic rocks in Romania. In: Downes $\mathrm{H}$, Vaselli $\mathrm{O}$ (eds) Neogene and related volcanism in the Carpatho-Pannonian Region. Acta Vulcanologica 7: 53-63

Pécskay Z, Lexa J, Szakács A, Seghedi I, Balogh K, Konečný V, Zelenka T, Kovacs M, Póka T, Fülöp A, Márton E, Panaiotu C, Cvetković V (2006) Geochronology of Neogene-Quaternary magmatism in the Carpathian arc and intra-Carpathian area: a review. Geol Carpath 57: $511-530$

Pedersen GBM, Grosse P (2014) Morphometry of subaerial shield volcanoes and glaciovolcanoes from Reykjanes peninsula, Iceland: effects of eruption environment. J Volcanol Geotherm Res 282:115133

Peltz S, Vajdea E, Balogh K, Pécskay Z (1987) Contributions to the geochronological study of the volcanic processes in the Călimani and Hargitha Mountains (East Carpathians, Romania). Dări de Seamă ale Sedintelor Inst. Geol Geofiz 72-73(1):323-338

Pike RJ, Clow GD (1981) Revised classification of terrestrial volcanoes and a catalog of topographic dimensions with new results on edifice volume. US Geol Surv Open-File Rep OF 81, 1038

Popa M, Radulian M, Szakács A, Seghedi I, Zaharia B (2012) New seismic and tomography data in the southern part of the Harghita Mountains (Romania, Southeastern Carpathians): connection with recent volcanic activity. Pure Appl Geophys 169(9):1557-1573

Press WH, Flannery BP, Teukolsky SA, Vetterling WT (1988) Numerical Recipes. Cambridge University Press

Priest S, Duffield WA, Malis-Clark K, Hendley II JW, Stauffer PH (2001) The San Francisco volcanic field Arizona. USGS Fact Sheet 017 $01,2 \mathrm{p}$

Ratdomopurbo A, Beauducel F, Subandriyo J, Agung Nandaka IGM, Newhall CG, Suhama SDS, Suparwaka H, Sunarta (2013) Overview of the 2006 eruption of Mt. Merapi. J Volcanol Geotherm Res 261:87-97

Ricci J, Lahitte P, Quidelleur X (2015) Construction and destruction rates of volcanoes within a tropical environment based on K-Ar dating and numerical reconstructions: examples from the Basse-Terre Island (Guadeloupe, Lesser Antilles). Geomorphology 228:597607

Riggs NR, Hurlbert JC, Schroeder TJ, Ward SA (1997) The interaction of volcanism and sedimentation in the proximal areas of a mid-tertiary volcanic dome field, Central Arizona, USA. J Sediment Res 67: $142-153$

Rose WL (1987) Volcanic activity at Santiaguito volcano 1976-1984. Geol Soc Am Bull Spec Pap 212:17-27

Ryan GA, Loughlin SC, James MR, Jones LD, Calder ES, Christopher T, Strutt MH, Wadge G (2010) Growth of the lava dome and extrusion rates at Soufriere Hills Volcano, Montserrat West Indies: 20052008. Geophys Res Lett 37:L00E08. https://doi.org/10.1029/ 2009GL041477

Salvany T, Lahitte P, Nativel P, Gillot PY (2012) Geomorphic evolution of the Piton des Neiges volcano (Réunion Island, Indian Ocean): competition between volcanic construction and erosion since 1.4 Ma. Geomorphology 136:132-147

Saunders I, Young A (1983) Rates of surface process on slopes, slope retreat and denudation. Earth Surf Process Landf 8:473-501

Scott WE, Sherrod DR, Gardner CA (2008) Overview of the 2004 to 2006, and Continuing, Eruption of Mount St. Helens, Washington. In: Sherrod DR, Scott WE, Stauffer PH (eds) A Volcano Rekindled: The First Year of Renewed Eruption at Mount St. Helens, 2004 2006. US Geol Surv Prof Pap 1750, p 856

Seghedi I, Szakács A, Udrescu C, Stoian M, Grabari G (1987) Trace element geochemistry of the South Harghita volcanics (East Carpathians). Calc-alkaline and shoshonitic association. D S Inst Geol Geofiz 72-73/1:381-397

Seghedi I, Balintoni I, Szakács A (1998) Interplay of tectonics and neogene postcollisional magmatism in the intracarpathian region. Lithos 45(1-4):483-497

Seghedi I, Downes H, Szakács A, Mason PRD, Thirlwall MF, Roșu E, Pécskay Z, Márton E, Panaiotu C (2004) Neogene-Quaternary magmatism and geodynamics in the Carpathian-Pannonian region: a synthesis. Lithos 72:117-146

Siswowidjoyo S, Suryo I, Yokoyama I (1995) Magma eruption rates of Merapi volcano, Central Java, Indonesia during one century (1890 1992). Bull Volcanol 57:111-116

Smith IEM, Németh K (2017) Source to surface model of monogenetic volcanism: a critical review. In: Németh K, Carrasco-Nuñez G, Aranda-Gomez JJ, Smith IEM (eds) Monogenetic Volcanism. Geol Soc London spec Publ 446: 1-28

Stoiber RE, Carr MJ (1973) Quaternary volcanic and tectonic segmentation of Central America. Bull Volcanol 37:304-325 
Summerfield MA (1991) Global geomorphology. An lntroduction to the study of landforms. Longman Sci Tech, Harlow, copublished with Wiley, New York, NY, $537 \mathrm{p}$

Swanson D, Holcomb R (1990) Regularities in growth of the Mount St. Helens dacite dome, 1980-1986. In: Fink JH (ed) Lava flows and domes: emplacement mechanisms and Hazard implications (IAVCEI pro, 3-24 pp). Springer-Verlag, Berlin

Szakács A (2010) Post-volcanic Phenomena in the East Carpathians. In: Evelpidou N, de Figueiredo T, Mauro F, Tecim V, Vassilopoulos A (Eds) Natural heritage from East to West. Case studies from $6 \mathrm{EU}$ Countries, Springer Verlag, ISBN 978-3-642-01576-2, 87-93 pp

Szakács A, Seghedi I (1986) Chemical diagnosis of the volcanics from the Southeasternmost part of the Harghita Mts. Proposal for a new nomenclature. Rev Roum Geol Geophys Geogr Geologie 30:41-48

Szakács A, Seghedi I (1990) Quaternary dacitic volcanism in the Ciomadul massif (South Harghita Mts, East Carpathians). IAVCEI general assembly, 3-8 September 1990, abstract volume, Mainz

Szakács A, Seghedi I (1995) The Călimani-Gurghiu-Harghita volcanic chain, East Carpathians, Romania: volcanological features. Acta Vulcanol 7:145-153

Szakács A, Seghedi I, Pécskay Z (1993) Pecularities of South Harghita Mts. as the terminal segment of the Carpathian Neogene to Quaternary volcanic chain. Rev Roum Geol Geophys Geogr Ser Geologie 37:21-36

Szakács A, Seghedi I, Pécskay Z, Mirea V (2015) Eruptive history of a low-frequency and low-output rate Pleistocene volcano, Ciomadul, South Harghita Mts., Romania. Bull Volcanol 77:12

Tanaka KL, Shoemaker EM, Ulrich GE, Wolfe EW (1986) Migration of volcanism in the San Francisco volcanic field, Arizona. Geol Soc Am Bull 97(2):129-141

Tatsumi Y, Suzuki-Kamata K, Matsuno T, Ichihara H, Seama N, Kiyosugi K, Nakaoka R, Nakahigashi K, Takizawa H, Hayashi K, Chiba T, Shimizu S, Sano M, Iwamaru H, Morozumi H, Sugioka H, Yamamoto Y (2018) Giant rhyolite lava dome formation after 7.3 ka supereruption at Kikai caldera, SW Japan. Sci Rep 8(1):2753

Taylor GA (1958) The 1951 eruption of mount lamington, Papua. Aust Bur Min Resour Geol Geophys Bull 38:1-117

Telbisz T, Karátson D, Látos T (2017) Vulkánok térfogatszámításával kapcsolatos módszertani kérdések (methodological problems in connection with volcano volumetry: in Hungarian). Az elmélet és a gyakorlat találkozása a térinformatikában (theory meets practice in GIS), 8th Conf, Debrecen University Press, 367-374 pp

Veres D, Cosac M, Schmidt C, Murătoreanu G, Hambach U, Hubay K, Wulf S, Karátson D (2018) New chronological constraints for middle Palaeolithic cave sequences in eastern Transylvania, Romania. Quat Int 485:103-114

Vinkler AP, Harangi SZ, Ntaflos T, Szakács A (2007) Petrology and geochemistry of pumices from the Ciomadul volcano (Eastern Carpathians) - implication for petrogenetic processes. (in Hungarian with an English abstract). Földtani Közlöny 137(1): 103-128

Voight B, Constantine EK, Siswowidjoyo S, Torley R (2000) Historical eruptions of Merapi volcano, Central Java, Indonesia, 1768-1998. J Volcanol Geotherm Res 100:69-138

Wadge G, Herd R, Ryan G, Calder ES, Komorowski J-C (2010) Lava production at Soufrière Hills Volcano, Montserrat: 1995-2009. Geophys Res Lett 37:L00E03. https://doi.org/10.1029/ 2009GL041466

White SM, Crisp JA, Spera FJ (2006) Long-term volumetric eruption rates and magma budgets. Geochem Geophys Geosyst 7(1):1-20

Wohletz K, Heiken G (1992) Volcanology and geothermal energy. University of California Press, Berkeley, $432 \mathrm{p}$

Wolpert RL, Ogburn SE, Calder ES (2015) The longevity of lava dome eruptions. J Geophys Res Solid Earth 121(2):676-686

Wood CA, Kienle J (1990) Volcanoes of North America: United States and Canada. Cambridge University Press, NY 354 p

Wulf S, Fedoriwicz S, Veres D, Lanczont M, Karátson D, Gertisser R, Bormann M, Magyari EK, Appelt O, Hambach U, Gozhyk PF (2016) The 'Roxolany Tephra' (Ukraine) - new evidence for an origin from Ciomadul volcano, East Carpathians. J Quat Sci 31: $565-576$

Yanalak M, Baykal O (2003) Digital elevation model based volume calculations using topographical data. J Surv Eng 129(2):56-64

Yokoyama I (2005) Growth rates lava domes with respect to viscosity of magmas. Ann Geophys 48(6):957-971 